Shifting perceptions: Lessons from an exploratory study of the Inside Criminal Justice Program

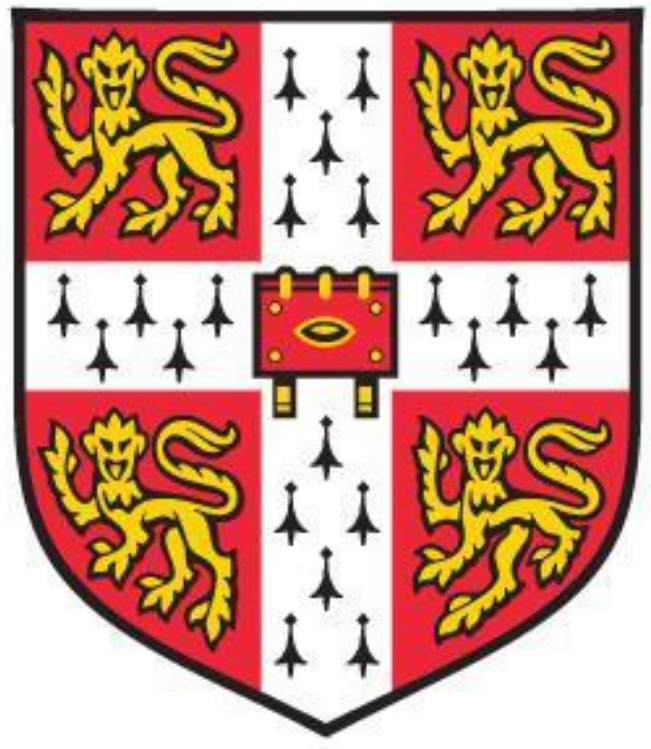

Nicole Emilia Delgadillo

Clare College

MPhil in Criminological Research

Institute of Criminology

University of Cambridge

Submitted 22 September 2020

This dissertation is submitted in partial fulfillment of the requirements of the degree of Master of Philosophy

Supervised by Dr. Bethany Schmidt 


\section{Declarations}

This dissertation is the result of my own work, and includes nothing which is the outcome of work done in collaboration except where specifically indicated in the text.

This dissertation does not exceed the word limit as set out by the Degree Committee of the Faculty of Law. The total word count is: 17,989 words, including footnotes.

Signed: Niorh Lelgndill

Nicole Emilia Delgadillo

Submitted 22 September 2020 


\section{Acknowledgements}

Thank you to Dr. Geraldine Downey, Dr. Claudia P. Rincón, IIP Director Lucy Lang, Johnathan Terry, Lebo Hunter, Ivan Calaff, Jarrell Daniels, and Ayanna Sorrett for all your feedback and support during this process. It has been a privilege to learn from you and to work alongside you on this incredible program. Thank you for allowing me to document it.

Thank you to all the ICJ participants who took the time to speak candidly to me about their experiences with not only this program, but with the larger criminal-legal system in the US. Without your honesty and insight, this dissertation would be nonexistent.

Thank you to all my formerly incarcerated colleagues, friends, family, and students whose lived experiences guide my work and who should be centered in conversations like this, along with the many others still behind bars. Thank you for sharing your wealth of knowledge and expertise with me. I continue to learn from and follow your example.

To my superhero supervisor, Bethany Schmidt, thank you for your endless wisdom, encouragement, and belief in me throughout this entire process. I don't know if I would have actually made it to the finish line without your help.

To my friends, thank you for listening to me alternatively bore you to tears or rant away about mass incarceration for years, and for cheering me through this. You have kept me laughing, honest, moderately sane, and focused on what's ultimately important.

Finally, and most importantly, to my family, this is for you. This degree is as much yours as it is mine. Your unwavering faith in me and love have made this all possible. To the one who never doubted I would be here, Aueto, a ti dedico todo, y juntos, triunfamos.

When I came to realize,

there is no surprise, to the varied kaleidoscope

of human experience. 


\section{There is a profound \\ resilience, \\ I can see and feel it, \\ to the human spirit.}

-Dario Peña, poet and ICJ participant (used with the author's permission) 


\title{
Shifting perceptions: Lessons from an exploratory study of the Inside Criminal Justice Program
}

\begin{abstract}
:
This is an exploratory study of the efficacy of Inside Criminal Justice (ICJ), an eight-week long course for incarcerated students and public prosecutors that fosters respectful and open discussions about the criminal-legal system in order to rethink public safety. ICJ's impact falls within applied contact theory, intergroup relations, and interventions aimed at reducing bias.
\end{abstract}

The ICJ course was founded in 2018 as a joint initiative between three key institutions in the TriState Area (New York, New Jersey, Connecticut): the District Attorney’s Office, the Department of Corrections and Community Supervision (DOCCS), and Columbia University. ICJ brings current prosecutors inside correctional facilities to learn about and discuss issues of criminal justice alongside incarcerated students while developing joint policy proposals centered on improving the justice system. This program is the first of its kind in the area.

Through semi-structured interviews of students and prosecutors from across the seven cohorts and qualitative data analysis, this dissertation considers the impact of ICJ on three domains: preexisting beliefs related to the justice system, changes to concrete behaviors, and network building/transformation. It presents evidence of a reciprocal humanizing experience for its participants that helps shift perceptions, as suggested by Allport's (1954) contact hypothesis. It then examines the translation of that shift to individual and larger-scale changes resulting from ICJ involvement, and explores the distinct forms of credibility ICJ networks give to its participants as well as the ways network failure contribute to justice involvement. There is limited literature about programs that bring these types of criminal justice actors together in an educational setting. In addition to informing a larger, more systematic program evaluation, this exploratory study identifies key themes for future exploration, and presents evidence about the program's efficacy. 


\section{Table of Contents}

List of key abbreviations: .......................................................................................................................... vii

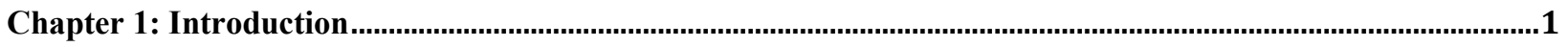

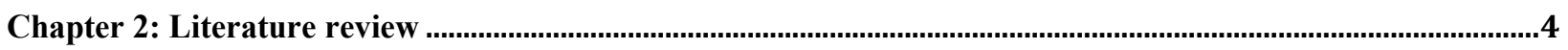

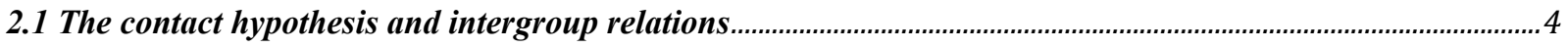

2.2 The Inside Criminal Justice (ICJ) seminar course and the role of the prosecutor.................................................

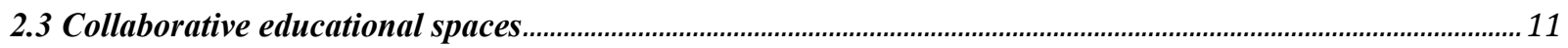

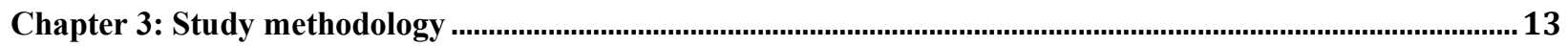

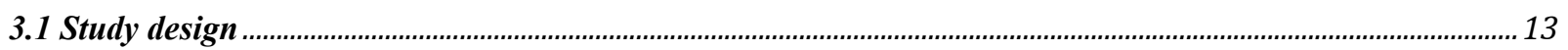

3.2 Participant recruitment ........................................................................................................................................................... 14

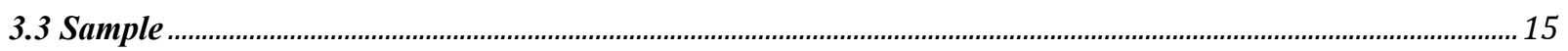

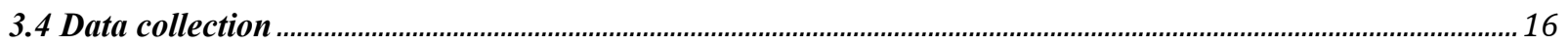

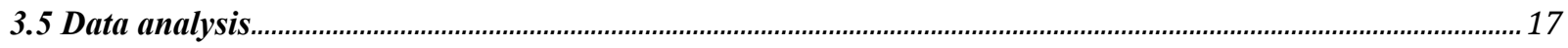

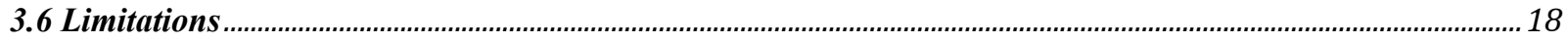

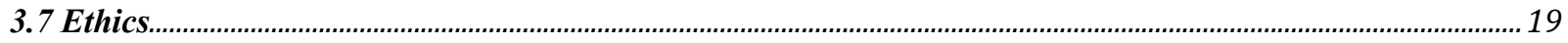

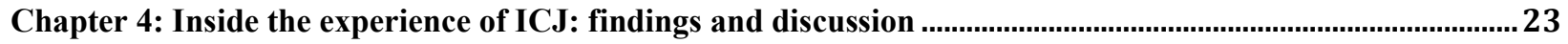

4.1 Contact theory and humanization of the adversarial other....................................................................................

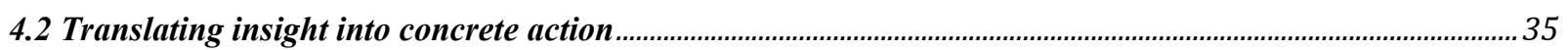

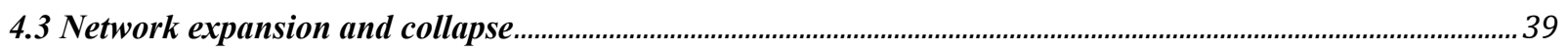

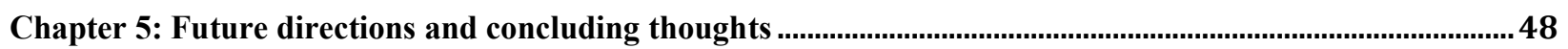

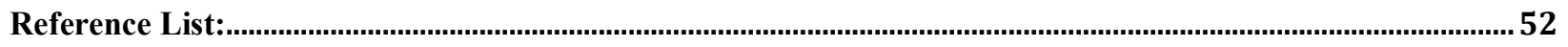

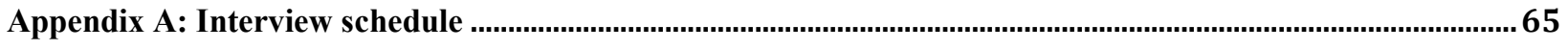

Appendix B: Study participant information and consent form ................................................................ 71

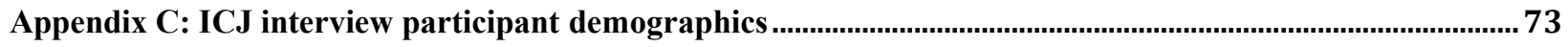

Appendix D: Resource sheet for study participants (abbreviated) ……......................................................... 74

Appendix E: Considerations for practitioners of ICJ ……........................................................................ 77 


\section{List of key abbreviations:}

ADA: Assistant District Attorney

DA: District Attorney

DOCCS: Department of Corrections and Community Supervision

CfJ: Center for Justice at Columbia University

CLE: Continuing Legal Education

ICJ: Inside Criminal Justice

IIP: Institute for Innovation in Prosecution at John Jay College of Criminal Justice

IRB: Institutional Review Board 


\section{Chapter 1: Introduction}

In discussions of tension between law enforcement and communities in the United States, much of the focus has historically been placed on the police; however, there is another key actor within the realm of law enforcement with an arguably equally tense relationship with the communities they serve: prosecutors. Arguably two of the most adversarial opponents in the criminal-legal system are the prosecutor, who tries cases on behalf of the state's interests, and the defendant, the accused trying to prove their innocence, who seldom meet outside of the courtroom. It is even rarer for a prosecutor to interact with an incarcerated person outside of preparing for a case (i.e. interviews with cooperating witnesses, plea bargains). Inside Criminal Justice (ICJ) is a unique program that brings together incarcerated students and prosecutors inside of correctional facilities in the Tri-State Area (Connecticut, New Jersey, and New York) to learn about criminal justice over the span of two months. ICJ uses key aspects of Gordon W. Allport's (1979) contact hypothesis to create an environment where adversaries in the US criminal-legal system (i.e. prosecutors and defendants/incarcerated people, correctional officers and incarcerated people, families of the prosecution and the defense) can learn together, devise creative solutions to the problems they see around them, and humanize each other in the process. ICJ was designed to focus on prosecutors and incarcerated students, with the hope of not only creating a productive, educational space to honestly discuss justice-related issues, but shifting perceptions in the process. ICJ represents a sustained contact experience as per the contact hypothesis, which theorizes that meaningful interaction under specific conditions can help combat negative stereotypes and prejudices.

As a common law country, the US uses an adversarial system of criminal justice, in which opposing parties (prosecution and defense attorney) present their case before an impartial body (i.e. a judge or a jury of peers) in an attempt to persuade that body to decide in its favor (Kuiper, 2011). The American prosecutor is considered an arm of the state or federal government, while in the UK, prosecution is carried out in the name of the Crown (Encyclopedia Britannica, 2002). The US is the only country whose citizens elect prosecutors to their offices, originating in the idea that "popular election would give citizens greater control over government, eliminate patronage appointments, and increase the responsiveness of prosecutors to the communities they 
served" (Ellis, 2012, p. 1531). However, between 1996-2006, 85 percent of incumbent prosecutors ran unopposed, and had a reelection rate of 95 percent (Wright, 2009). In the TriState Area, the District Attorney (DA) is elected for a four-year term and can be reelected multiple times. The DA is responsible for setting policy for the office (i.e. determining what kinds of crimes will be priorities for the DA's Office to try, and allocating resources). Assistant District Attorneys (ADAs) are the lawyers who then enact policy through trying cases, working on appeals, and developing policy relevant to the Office's stance on legal issues. The term "prosecutor" can be used either to refer to ADAs to differentiate them from counsel representing the defendant, as well as to the office that approves and brings charges in criminal cases. The DA and ADAs are considered to be part of law enforcement, with the DA as the highest elected level.

There is a strong sense of disconnect between those who enforce the law and those who live under it; that law enforcement does not understand the realities of the people in America's most vulnerable communities, nor does it particularly seem to care. In particular, prosecutors can be seen as wielding tremendous power, those who execute judgement without any regard to the challenges and nuances of crime and of the lives of those who engage in it: "Although prosecutors are not responsible for the conditions that spawn crime, the criminal laws that unfairly penalize conduct engaged in by some citizens and not others....prosecutors routinely validate and perpetuate this sorry state of affairs" (Smith, 2001, p. 372-373). This apathy is not only felt by defendants being tried by prosecutors, but by the survivors for whom justice is being sought. A nationwide survey found that six out of ten crime victims surveyed wanted prosecutors to take into account what would be most beneficial for victims' recovery, even when that meant shorter prison sentences (Alliance for Safety and Justice, 2016). In fact, 77 percent of violent crime survivors and 77 percent of serious violent crime survivors thought that the role of the prosecutor should center on solving neighborhood problems and stopping repeat crimes through rehabilitation, even when that meant decreased conviction rates and sentences (Alliance for Safety and Justice, 2016).

This dissertation argues that ICJ is effective at shifting negative narratives of adversarial criminal justice actors--prosecutors and incarcerated students. In his seminal 1954 work, The Nature of 
Prejudice, Allport posits that intergroup exposure can reduce prejudice under the following conditions: equal status, a shared goal, intergroup cooperation, and a shared system of authority. I use the contact hypothesis to demonstrate how ICJ implements these four conditions as well as operates as the proposed framework for how these perceptual shifts occur and that their effects ripple out at the individual and network levels. Allport's contact hypothesis was selected because interviewees in focus groups and in the study continually referenced an idea of a humanizing process and his work most clearly demonstrates the efficacy of this program with regard to providing a mechanism for deconstructing negative stereotypes.

In this historical moment, the US is becoming a nation defined by its relationship to its criminallegal system, as greater numbers of American citizens become entangled in its grasp. This speaks to the importance of programs like ICJ and of evaluating their efficacy. Currently, the US incarcerates 655 per 100,000 of its people, the highest incarceration rate in the world (World Prison Brief, 2019) and roughly 6,410,000 individuals are under some kind of correctional supervision (incarceration or community supervision) (Maruschak and Minton, 2020). Despite the increased numbers of people in the system, there appears to be a lack of a corresponding meaningful interaction between people impacted by the system and individuals shaping movement (i.e. prosecuting) of people in the system. ICJ seeks to address this discrepancy. My dissertation seeks to understand how, whether, and why this program is effective. Likewise, I seek to contribute to finding ways to increase intergroup relations between adversarial criminal justice actors to facilitate positive change.

How do we bridge this disconnect between those who enforce the law and those most impacted by it? There is an interest in investigating solutions that allow law enforcement to understand the lived realities of their constituents, while giving those who are disproportionately affected by those disparities a chance to voice their ideas for change to law enforcement entities. This dissertation is an exploratory qualitative study of the impact of the ICJ program on its participants, focusing on shifts in perception towards humanizing perspectives, resulting behavioral change, and the role of networks to both provide positive credibility or contribute negatively to justice involvement. 


\section{Chapter 2: Literature review}

This chapter provides a review of the literature relevant to understanding the ICJ program and the theoretical framework for this dissertation. To first understand the underlying ideas of ICJ, the chapter offers an overview of the contact hypothesis and its role within scholarship about intergroup relations. Then, the ICJ program is described in-depth along with a brief discussion of the prosecutor's role within the American criminal-legal system. Attention is given to collaborative educational spaces.

\subsection{The contact hypothesis and intergroup relations}

The most well-known and widely studied version of the contact hypothesis is that of Gordon W. Allport in his seminal 1954 work, The Nature of Prejudice. In discussing the "intricate checkerboard of prejudice in the United States," he writes, "while some of this endless antagonism seems based upon a realistic conflict of interest, most of it, we suspect, is a product of the fears of the imagination. Yet imaginary fears can cause real suffering" (Allport, 1979, p. $\mathrm{XV}$ ). Initially developed in response to segregation and ongoing racial tensions in the US, Allport's primary focus was on racial prejudice. He, however, acknowledge other kinds of prejudice and his conclusions are more generalizable to the concept of prejudice as a whole. The Nature of Prejudice outlines the variety of ways that prejudice and stereotypes are formed and reinforced, as well as some potential solutions to combat this.

The concept of prejudice contains two key components: "there must be an attitude of favor or disfavor; and it must be related to an overgeneralized (therefore erroneous) belief [emphasis in original]" (Allport, 1979, p. 13). While both are typically present, "beliefs, to some extent, can be rationally attacked and altered...however, they have the slippery propensity of accommodating themselves somehow to the negative attitude which is much harder to change" (ibid: 13). The human brain is evolutionarily trained to create categories to help us understand and respond to the various circumstances we find ourselves in based on previous experiences. It serves a practical and essential function attuned to increasing our survival: "The ability to use past experiences and information about our current state and environment to predict the future allows us to increase the odds of desired outcomes, while avoiding or bracing ourselves for future adversity" (Grupe and Nitschke, 2013, p. 488). The process of categorization or generalization is 
an inevitable, normal and natural tendency, and thus, humans have a propensity for prejudice (Allport, 1979, p. 27).

How then can we undo this process our brain is wired to accomplish? Per Allport, the underlying logic of the contact hypothesis stems from the assumption that contact and acquaintance with a person produces friendliness. However, unstructured interactions that occur in an environment that reproduce hierarchical structures (i.e. power imbalances) or between groups that see each other as threats can be harmful rather than helpful. The absence of a clear, objective goal in such interactions can produce frustration or antagonism (Allport, 1979, p. 488-9). Thus, Allport (1979, p. 489) theorizes four optimal conditions that contact experiences between prejudicial groups should follow:

To be maximally effective, contact and acquaintance programs should lead to a sense of equality in social status, should occur in ordinary purposeful pursuits, avoid artificiality, and if possible, enjoy the sanction of the community in which they occur. The deeper and more genuine the association, the greater the effect. While it may help somewhat to place members of different ethnic groups side by side on a job, the gain is greater if these members regard themselves as part of a team [emphasis in original].

These conditions are often summarized as: equal status, intergroup collaboration, common goals, and support of authorities, laws, or customs (institutional support) (Pettigrew and Tropp, 2006). However, these conditions themselves are quite nebulous in terms of what they mean in practice, especially with regard to common goals and collaboration, sometimes conceptualized as "cooperative interdependence" which entails members of two groups working together towards a shared goal (Koschate and van Dick, 2011). For Gaertner et al. (1999), “cooperative independence" consists of two elements: positive interdependence of goals (for one to succeed, both must) and cooperative interaction (assisting each other on a task, engaging in conflict resolution, and communicating). By manipulating both elements in a lab setting, only cooperative interaction reduced self-reported measures of bias, suggesting that interaction is key (Gaertner et al., 1999). 
Acquaintanceship or friendship has also been suggested as another condition for a successful contact encounter (Cook, 1985; Pettigrew, 1998), though in the original hypothesis, friendship is facilitative, rather than essential (Koschate and van Dick, 2011). Of note, in a study of students, acquaintanceship was found to be one of the most robust predictors of prejudice reduction (Molina and Wittig, 2006). However, the contact hypothesis has been critiqued because it can be difficult to create situations in which all conditions are met; because the conditions specified by Allport seldom occur organically and therefore, must be engineered to some extent, its positive effects may not be generalizable to "everyday life in divided societies" (Dixon et al., 2005, p. 697).

Related is "in-groups" and "out-groups", an idea included in Allport's examination of the formation of prejudice. While social groups can provide a sense of social identity, we create ingroups ("us") and out-groups ("them") through the natural process of social categorization and stereotyping (Allport, 1979), which can lead to exaggerations of both in-group favoritism and out-group discrimination (Tajfel and Turner, 1979). This may manifest in higher levels of prejudice and hostility or increased efforts to differentiate the in-group from other groups. Tajfel and Turner's (1979) social identity theory presents three stages in the mental processes of evaluating these in-groups and out-groups: social categorization, social identification, and social comparison. Social categorization is first used to understand our social environment by organizing people and ourselves within it, while social identification concerns adopting the norms of the group that we have categorized ourselves as, ultimately leading to social comparison once we have identified with a group (Tajfel and Turner, 1979). Critically, the theory notes that there is an emotional significance with social identification, and resultantly, an individual's self-esteem can become entangled with their group membership. Once groups identify themselves as opponents, they are forced to compete to maintain self-esteem; ergo, competition and hostility between adversarial groups is a product of competing identities (Tajfel and Turner, 1979). Also important to consider is realistic conflict theory, which proposes that competition over limited resources can produce conflict and prejudice between groups (Sherif et al., 1988). Realistic conflict theory does not require the existence of real competition over resources, but rather, the perception of competition, leading to conflict and intergroup hostility (Esses et al., 1998). Thus, in some ways, prejudice and hostility are rooted in conflicting interests 
between groups: when groups share goals that are compatible, positive behavior and attitudes are more likely to exist, whereas the converse becomes true when goals are incompatible (Campbell, 1965). Allport's condition of collaboration can then be interpreted, as per Campbell, as a way of aligning opposing groups to a shared goal to help eliminate this perception of competition.

Meta-analyses offer clear indications that intergroup contact does typically reduce prejudice (Paluck et al., 2018; Pettigrew and Tropp, 2006). However, there remains some level of debate about how critical Allport's four conditions are to creating that outcome. Pettigrew and Tropp (2006), for example, suggest that Allport's conditions are helpful, but not critical, in reducing bias amongst majority and minority groups, whilst Paluck et al. (2018) found that these conditions have not been sufficiently studied to determine their role. Some evidence suggests that Allport's contact conditions may be better studied as separate predictors rather than as an aggregated index of quality of contact (Koschate and van Dick, 2011).

The challenges of desegregation in the US caused Allport's ideas to rise in prominence as social scientists began to reframe and test the contact hypothesis in relation to the ramifications of school, neighborhood, and workplace desegregation and the corresponding legal and political issues (Cook, 1985). The contact hypothesis is ideally situated as both a theoretical framework and a political tool: "Thus, at its inception, the contact hypothesis served both an academic and a policy agenda" (Paluck et al., 2018). It has been applied to other kinds of prejudice, stigma, and discrimination including gender identity (Broockman and Kalla, 2016), sexual orientation (Dessel, 2010), and age (Meshel and MCGlynn, 2004). The contact hypothesis has also been used to frame peacebuilding interventions (Mania et al., 2009).

Within criminology, restorative justice (RJ) practices follow similar conditions of contact theory: the main elements include voluntariness for all involved parties, honesty and truth-telling, and face-to-face interaction in a safe and organized setting in order to collectively determine appropriate methods of harm reparation (Llewellyn and Howse, 1998). As Zehr (1990) posited, crime is a violation of people and interpersonal relationships, that creates an obligation to correct the harm done to the victim and the community, rather than purely a violation of law. Because the focus centers on the destruction or harm to relationships, restorative justice recognizes that 
the solution also lies in a focus on repairing these relationships, much in the same way the contact hypothesis uses interaction and relationship-building to mitigate or undo the harm done by prejudicial attitudes. To my knowledge, the contact hypothesis has not been explicitly applied to prosecutors and incarcerated individuals before, as is the case with ICJ.

\subsection{The Inside Criminal Justice (ICJ) seminar course and the role of the prosecutor}

ICJ began in the winter of 2018 as a collaboration between the District Attorney's (DA) Office, the Center for Justice (CfJ) at Columbia University, and the Department of Corrections and Community Supervision (DOCCS). It has since expanded to include the Institute for Innovation in Prosecution (IIP) at John Jay College of Criminal Justice. The program consists of a six-toeight-week long seminar based on a Columbia social psychology course. The seminar is held in a correctional facility, bringing participating assistant district attorneys (ADAs; more generically, prosecutors) inside to learn alongside and collaborate with incarcerated adult students. The seminar comprises class discussions and collaborative class activities, building toward the culminating joint policy proposal presentation ${ }^{1}$. Upon successful completion, ADAs receive Continuing Legal Education (CLE) credit and students receive three course credits from Columbia. Each class session is two hours long; prosecutors meet with students once a week to discuss course readings and relevant themes, and students attend an additional two-hour recitation session to review and enhance their understanding of the coursework to receive college credit. The course material "reviews and integrates current psychological research on the role of social factors in healthy and unhealthy personal, community and societal outcomes and considers how this knowledge can be translated into action to promote personal and societal health" (IIP, 2019). Class themes include RJ, healthy development throughout the life course, and the purpose of punishment. These conversations are facilitated by the two course instructors, one who is an ADA themselves and the other who is a psychology professor. The course is aided by a teaching assistant (TA) who is a member of the program's support staff and who provides feedback on written assignments, leads the student recitation session, and helps with breakout group discussions in class.

\footnotetext{
${ }^{1}$ For sample syllabi and class activities, see IIP, 2020.
} 
A cohort consists of the participants at one facility during one semester; there have been more than one cohort per semester as the program has grown to include more facilities ${ }^{2}$. ICJ cohorts ideally consist of equal numbers of ADAs and students (typically ten of each), however, in practice, a natural degree of attrition as the course progresses may shift this balance. Flyers and informal information sessions by ICJ staff at both the DA's Offices and at the correctional facilities help solicit interest. All participants must complete a short application, answering questions about motivation for joining the course, educational history, and desired outcome from the ICJ experience. Students must have a high school diploma or equivalent to earn course credit, however, those without a high school degree may still participate. ICJ staff reads through each application to determine the final roster, which is approved by the correctional facility, based on students' disciplinary histories and group dynamics (e.g.,. no members of rival gangs). The first cohort took place at a state male, minimum security facility focused on reentry, where individuals had less than 180 days left of their sentence, regardless of type of conviction.

ICJ seeks to engage two of the criminal-legal system's primary actors: prosecutors who bring charges on behalf of the state and incarcerated people who experience the lived reality of those charges. One of ICJ's primary goals is to encourage these groups to engage in meaningful, honest dialogues about their experiences with the system and what purpose that system should serve: "The objective is to think together about a justice system that emphasizes public safety while supporting healthy development from birth to old age and makes engaged citizenship possible for everyone" (IIP, 2019).

Starting in the third week, a portion of each class session is designated for group work on the joint criminal justice reform policy proposals, showcased in a fifteen-minute presentation at a final graduation ceremony in front of friends, family, colleagues, and representatives from local city and state agencies, including the partner organizations. Policy proposals have included: iPads in holding cells to provide more details about charges, pamphlets in courthouse lobbies about various resources (e.g.,. domestic violence, substance use), and reentry-focused computer labs in prison. The objective of the exercise is not only to collaborate and generate new solutions to existing issues, but to leverage the expertise of each group: the lived experience of

\footnotetext{
${ }^{2}$ Thus far, ICJ has been implemented at four state prisons and one city jail.
} 
incarcerated students, and the bureaucratic skill of the prosecutors. While this is an intellectual exercise, proposals are meant to be designed for practical implementation. There is no guarantee that any of the policy proposals will be adopted, yet the graduation ceremony gives participants the platform to present their ideas to individuals with the capacity to implement them. Following the contact hypothesis, Allport's (1979) conditions are satisfied through the policy proposal task (collaboration and common goal), presence of officials at graduation and the cooperation inherent in allowing the course to take place (institutional support), and universal learner identities throughout the course, culminating in equal voice in the policy presentation at graduation (equal status).

However, ICJ's scope goes beyond devising novel solutions: by fostering meaningful contact between two adversarial actors, a reciprocal humanization occurs, as theorized by the contact hypothesis. Because these individuals seldom meet outside of the high-stakes environment of the courtroom, it can be challenging to see each other as anything but a threat. Prosecutors were selected as the focus of ICJ because of the unique role that they occupy within the US criminallegal system.

Through prosecutorial discretion, prosecutors wield considerable power. From the initial choice to bring charges to decisions about a case's conclusion, prosecutorial discretion allows prosecutors to shape the entire process of a criminal case, a power subject to few checks (Beale, 2009). Prosecutorial discretion is of particular importance in the practice of plea bargaining, in which both parties reach an agreement, allowing the defendant to plead guilty or no contest in exchange for a concession from the prosecutor (i.e. offering a lesser charge, recommending shorter sentences). In the US, the vast majority of cases are resolved this way: the most recent Sourcebook of Federal Sentencing Statistics reports that 97.6 percent of federal cases were resolved with a guilty plea (US Sentencing Commission, 2019). In 2006, 94 percent of state felony conviction cases were resolved via a guilty plea (Rosenmerkel et al., 2010). In noting the particular power of the prosecutor in plea bargaining, Gifford (1983) writes that pleas "are not consensual agreements entered into by defendants after adversarial negotiations....'Plea bargaining' is in reality a prosecutor's unilateral administrative determination of a defendant's criminal culpability and the appropriate punishment for him" (ibid: 38). Due in part to renewed 
interest in the idea of prosecutorial discretion, prosecutors have reemerged recently as a popular focal point for reform within the criminal-legal system (Travis et al., 2019). Pfaff (2017) argues that the US prison population growth in the 1990s and 2000s can be attributed to increased prison admissions driven by the prosecutor's willingness to file felony charges that typically result in incarceration, rather than long sentences. Because ICJ is a young and unique program, no literature yet exists on its impact and there is limited research on the impact of exposing prosecutors to incarcerated students in a collaborative learning environment.

\subsection{Collaborative educational spaces}

Having established the theoretical framework of the contact hypothesis and an understanding of the ICJ program, we move to exploring the environmental and pedagogical approach that underlies ICJ: collaborative learning. Collaborative learning can be defined simply as "a situation in which two or more people learn or attempt to learn something together" (Dillenbourg, 1999, p. 1). There is some debate around the use of "collaborative" versus "cooperative," for there is a subtle difference: cooperative learning is often used for children and directed towards the acquisition of foundational knowledge (basic knowledge including grammar, math, etc), while collaborative learning refers to adult students engaging in nonfoundational knowledge acquisition, including critical reasoning or the construction of new knowledge (Bruffee, 1995). Contrastingly, for Panitz (1997: p. 3), "collaboration is a philosophy of interaction and personal lifestyle whereas cooperation is a structure of interaction designed to facilitate the accomplishment of an end product or goal". For the purpose of this dissertation and in reference to ICJ, the term "collaborative learning" is most appropriate in describing the ICJ model.

Collaborative learning has its theoretical underpinnings in the work of Lev Vygotsky's zone of proximal development, defined as "the distance between the actual developmental level as determined by independent problem-solving and the level of potential development as determined through problem solving under adult guidance or in collaboration with more capable peers" (Vygotsky and Cole, 1978, p. 86). Crucially, the skills being scaffolded are "those functions that have not yet matured but are in the process of maturation, functions that will mature tomorrow but are currently in an embryonic state" (Vygotsky and Cole, 1978, p. 86). 
Sadler-Smith (2005), distinguishing between individual and supraindividual learning, argues that the importance of collective learning is connected to Senge's (1990) assertion that collective learning creates a synergistic outcome where the group's knowledge exceeds the sum of that of its individual members. This focus on the aspect of the collective also points to the social network aspect of the learning process, therefore, "collective learning is fundamentally concerned with social interaction and the development of relational synergies" (Gubbins and MacCurtain, 2008, p. 578).

While collaborative learning may have its origins in the learning patterns of young children, it has been applied to a variety of other age groups and contexts. A 2013 meta-analysis of this learning model found more positive effects compared with traditional learning methods with a significantly positive effect for achievement and attitude; collaborative learning was also found to yield better results with primary (6-12 years) and tertiary level (18 years and older) participants (Kyndt et al., 2013). The Inside-Out Prison Exchange Program is a well-known and well-studied model of adult collaborative, experiential learning inside correctional facilities, and shares many similarities with ICJ. Founded in 1997, the Inside-Out Prison Exchange Program brings "outside" university students inside prison to learn alongside incarcerated college students in a variety of academic disciplines like criminal justice, English, and philosophy (Inside-Out, 2020). Dewey's theory of experiential learning states that the value of an educational experience lies in the convergence of the principles of interaction (a student's relationship with the immediate environment) and continuity (habits based on past experiences that inform future choices or student development) that produce lessons based on the explicit curriculum and from participating in those activities (collateral learning) (Dewey, 1938). Experiential learning should be structured in a way that promotes a mutually beneficial relationship between the learner and group of interest (Wright, 2000), and when done correctly, the process can provide lasting educational opportunities for both the students and the community they learn from and work alongside (Carver, 1997; Markus, et al. 1993). 


\section{Chapter 3: Study methodology}

This chapter offers a methodological overview of the practices used in this exploratory qualitative study of ICJ's impact. It begins with an outline of the study design and research questions, followed by an explanation of participant recruitment and description of the sample used in this dissertation's analysis. Data collection and pertinent challenges presented by COVID-19 are addressed, leading to a summary of the data analysis process, and concluding with a discussion of the study's limitations and ethics.

\subsection{Study design}

In order to explore the impact of ICJ through the lens of the contact hypothesis, semi-structured interviews were carried out in this exploratory study ${ }^{3}$. The semi-structured interview is flexible: it provides some parameters to the interview based on the research questions and proposed areas of interest, while still allowing the participant to shape the interview through tangents that give “insight into what the interviewee sees as relevant and important" (Bryman, 2012, p. 470). Particularly in thinking about questions of impact, it is key to give participants the space to discuss their own perceptions of impact, rather than guiding them to ideas that may not, in fact, be significant in their experiences. Additionally, because the research questions are descriptive in nature and seek to construct a detailed portrait of the ICJ experience, semi-structured interviews were the best method to capture richness and nuance as communicated through individual narratives. Based on the previously identified themes and literature in Chapter 2, this exploratory study seeks to address the following research questions:

- How do we understand the ICJ experience in the context of the contact hypothesis?

- Does participation in ICJ produce any significant changes in mindset about the perceived “other"? Does this mindset shift lead to any concrete changes in behavior?

- What impact, if any, does ICJ have on the social networks of participants?

\footnotetext{
${ }^{3}$ This study is also working to surface themes and questions to help inform a larger, more systematic evaluation as led by the Center for Justice (CfJ) and the Institute for Innovation in Prosecution (IIP). Because of that, I was assisted by the CfJ summer research assistant assigned to this project, Lebo Hunter, with participant outreach, data collection, and transcription. In total, thirty-one interviews were collected by myself and Lebo: twenty-five were collected by me, six were collected by Lebo. These thirty-one interviews also included five interviews with staff, which have been excluded from my qualitative analysis due to my focus on primary participants (i.e. students and prosecutors who completed the program).
} 
Interview questions were developed in collaboration with the Center for Justice (CfJ) team. Focus groups prior to my enrollment at Cambridge helped initial themes around the contact hypothesis and transformation to emerge, and were refined further throughout the process of designing and writing the interview schedule. I developed questions with the following themes in mind: the contact hypothesis (Allport, 1979), humanization/empathy (Stephan and Finlay, 1999), perspective-taking (Todd and Galinsky, 2014), generativity (Erikson, 1950), resilience (Freitas and Downey, 1998), social networks (Bronfenbrenner and Morris, 2006), growth mindset (Dweck, 2006) and sense of community (McMillan and Chavis, 1986). An initial set of 32 questions was informally piloted with $\mathrm{CfJ}$ affiliates to smooth out the language, see what kinds of responses were elicited by the questions, and get feedback on the questions themselves. The pilot interviews consisted of one formerly incarcerated CfJ staff member who had been a student inside, and one former ADA who has since left the DA's Office and is now working as a CfJ fellow (see Appendix A and B for the full interview schedule and consent form, respectively). Examples of interview questions include:

- Prior to this course, what were your opinions of prosecutors/law enforcement? Of incarcerated people?

- Did the course have any kind of lasting impact on you? If so, in what ways?

- What do you value about the relationships and connections you made as a result of being in the course?

\subsection{Participant recruitment}

All individuals who successfully completed the program through to graduation were eligible to be interviewed. For the purposes of clarity in this dissertation, "participant" or "graduate" will refer to all members of the ICJ cohort. "Student" will be used to refer to the incarcerated male participants, and "ADA" or "prosecutor" will refer to the Assistant District Attorneys. It is important to the work of ICJ and of this dissertation to use humanizing language, and to affirm the positive identity of the men here as learners, rather than defining them by their status within the system (e.g.,. "inmate", "prisoner", "felon", "convict", etc) and the accompanying negative stereotypes. For more on this, see Ellis (2007). 
Out of a total of 130 eligible participants, I was able to contact 85 people. 27 agreed to be interviewed, with 22 successfully interviewed. Some of the participants in this study had completed the course as recently as December 2019; for those in the earliest cohorts, up to two years had elapsed. While this delay was not intentional, it does provide an interesting point of comparison between those who recently completed the program and those who are a few years out, in addition to seeing whether or not the program had any impact now that a significant amount of time has passed. I employed snowball sampling, which as per Coleman (1958), can be a recommended strategy when networks of people are a focus. Snowball sampling is able to simultaneously maximize and unveil the connectedness of individuals in networks (Noy, 2008).

Participants were all recruited via email or text contact with someone that they already knew from their ICJ experience (i.e. support staff or instructors). A member of ICJ staff, following their own interview, reached out to potential participants with a virtual introduction and a brief description of the project. Additional permission from the DA's Offices was required to allow current prosecutors to be interviewed and recorded for this research.

\subsection{Sample}

I conducted twenty-two participant interviews total. One incomplete interview was removed from the sample. The analysis includes two participants who were ADA students in the course and then went on to teach. They were included because of their unique perspectives as primarily, graduates of the program, and subsequent facilitator roles. All interviews with formerly incarcerated students have all been included in the sample to provide as much representation of their voices as possible within the data set. This sample consists of fourteen prosecutors and seven students. All seven cohorts and all five facilities where the program was taught are represented in the sample by at least one student or prosecutor. For a more detailed breakdown, see Appendix C. My study did not directly collect participant demographic information, with the exception of length of involvement with the criminal justice system, and their cohort year, and facility, which was verified through program records and confirmed with the participant at the start of the interview. Information about participants' race was embedded in their answers to the interview questions. Nine interviewees identify as people of color; five interviewees are women. 
Participants ranged from a few years to over three decades of involvement with the criminal justice system (both personally and/or professionally).

\subsection{Data collection}

All interviews were conducted and recorded via Zoom. I also took written notes while conducting each interview, along with my thoughts post-interview, both as a way to summarize and to remain reflexive and introspective during the process of data collection. Following each interview, I downloaded the audio recording and deleted the video recording from my account. From there, I uploaded the recording to an encrypted hard drive. I used the transcription service Rev.com to assist with producing a preliminary transcript, as approved by Columbia's Institutional Review Board (IRB), to save time. Rev.com is widely used by researchers at Columbia and at CfJ: the site encrypts all data and all of Rev's transcribers sign a legally-binding confidentiality agreement. I used the automated service rather than the human transcriber service because it was more cost-effective and faster: the automated service can produce a transcript in a matter of minutes. To ensure its accuracy and to correct any errors, I went back and listened through each interview while reading the transcript and made corrections as necessary. All potentially identifying information was redacted from the transcript to maintain participant confidentiality. Once the transcription of the interview was complete, the audio file was permanently deleted. Non-fluencies were left in the original transcripts, but have been edited out for the quotations in the findings chapter for clarity and readability.

A note on COVID-19: Originally, the majority of the interviews were meant to be conducted in person, with phone interviews being reserved for those who had moved out of the Tri-State Area. However, with the restrictions put in place by the COVID-19 pandemic, all interviews were switched to a digital format. This required additional approval from the IRB to conduct and record interviews via Zoom. Zoom was ultimately selected because of its increased and widespread prevalence in tele-working, as well as its built-in recording feature. While some students are not as comfortable with Internet technology due to lack of access while incarcerated, Zoom is also fairly user-friendly. In addition, Zoom's video function helps to more closely approximate an in-person conversation. Zoom did present some challenges for a few participants, in which case, I called the participant via Google Voice on a laptop computer while recording the 
Zoom meeting. The original protocol and consent form were amended and approved for verbal consent. Consistent with all IRB protocol, participants were emailed the study information and consent form in advance (see Appendix B) which indicated that the conversation would be recorded. Participants were asked again for consent to record at the start of the conversation. Participant compensation also had to be mailed at the conclusion of the interview.

\subsection{Data analysis}

Qualitative data analysis was supported by the use of the NVIVO-12 software. Given the large amount of transcript data (close to 500 pages), it seemed best to use a program that could assist in organizing the data as well as look for themes that my own analysis may have missed, using the word count and text query functions. The 21 interviews in the sample were uploaded to NVIVO and assigned basic attribute markers (participant type, facility, cohort semester, gender, and race/ethnicity). The node structure that I created can be seen in Figure 3.1 (below). There are three parent nodes: research questions, text queries, and topic areas. Under "Research questions", each of the target areas from the interview schedule was given a child node. I created a "Topic areas" parent node for themes that were not directly related to the research questions, but had surfaced as prominent topics as I reviewed the transcripts. These child nodes were: "Program suggestions", "Reentry", and "What does justice look like?". The "Text queries" node was added to give myself a place to save the related searches for words associated with each target area, as well as more exploratory text queries. 
Figure 1: NVIVO ICJ coding structure

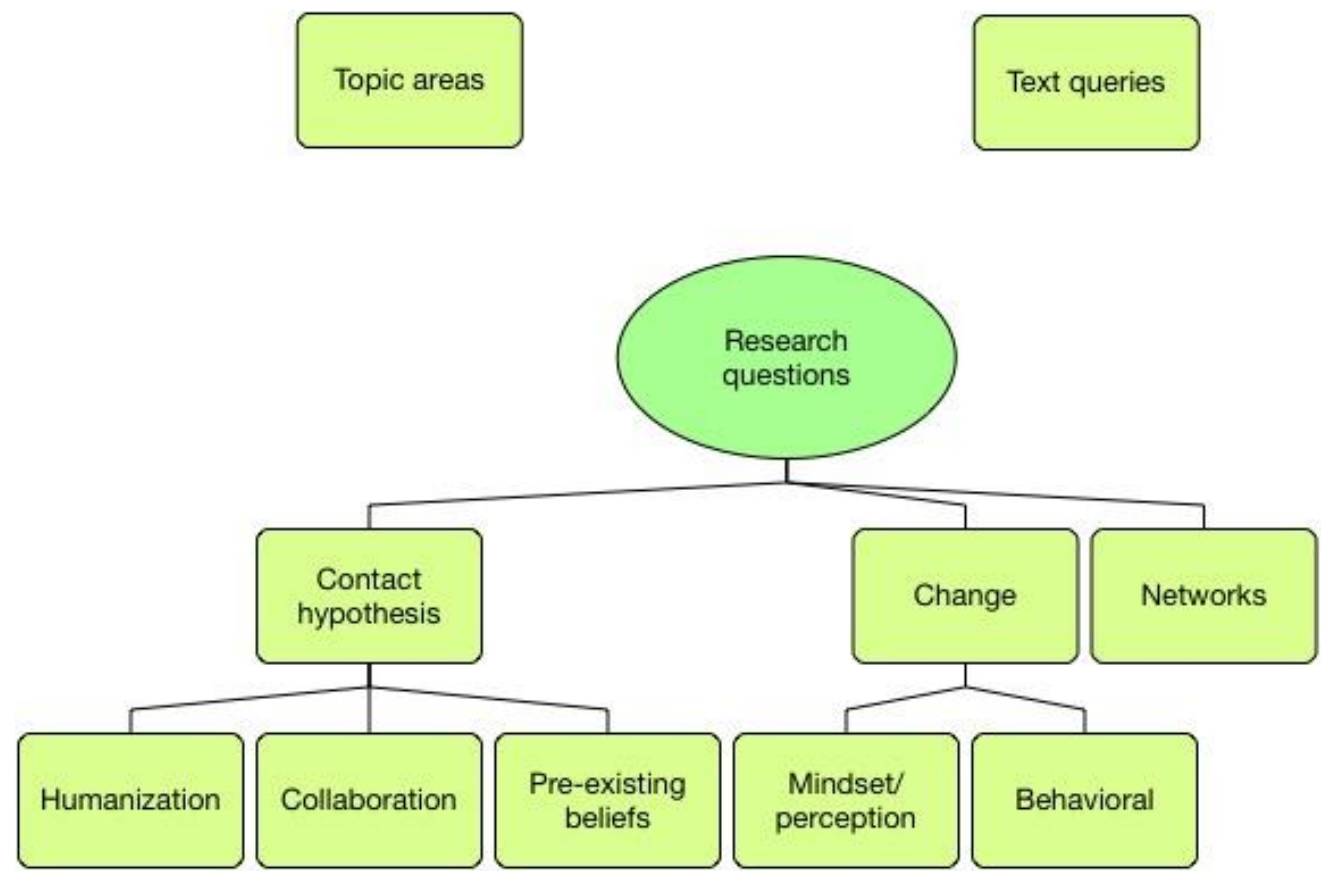

\subsection{Limitations}

Maslow's (1954) oft-cited hierarchy of needs posits five categories of human needs:

physiological, safety and security, belongingness, esteem, and finally, self-actualization.

Critically, each category of needs must be addressed and satisfied before an individual can continue to advance; in other words, fundamental needs like shelter, safety and physical wellbeing must be met before an individual can move on to more abstract goals like selfactualization (Maslow, 1954). Upon their return home, many formerly incarcerated individuals do not have their basic needs met, in addition to navigating a world that may feel foreign to them, especially if they had been incarcerated for extended periods of time. The need to secure basic resources makes it difficult to focus any cognitive resources towards higher-level needs. The narrative of reentry was often characterized by participants as a series of systemic hurdles that rendered returning people as "handicapped at every conceivable point" (Prosecutor 03): "many of the failings of penal practice have their origins in the difficulties of life before and after prison, as the prisoner starkly reflects, above ('I've never been treated like a human being in my whole life'). Reform projects fail when the struggles and dramas that underlie them are denied" (Liebling et al., 2019). In that vein, a few students have returned to custody since their ICJ involvement, due in part, as Liebling notes, to pre-existing circumstances prior to and continued 
after their incarceration. This is all to say that while programs like ICJ may have truly remarkable success stories--including one student enrolling at a prestigious university to get his bachelor's degree--that should be highlighted, it is also critical to acknowledge the very real challenges of reentry in the US. ICJ's focus is education: it is not a reentry program, nor are the CfJ or the IIP reentry organizations. Attempts were made to connect students to local organizations specializing in reentry, as well as on-going efforts by staff to support those with whom they had forged individual friendships. However, it is evident that this course did not change the material reality and hardships faced by formerly incarcerated people. One course cannot and will not solve the systemic issues at play.

Additionally, all of this research was done retrospectively: it would be beneficial to collect data about each participant's baseline (i.e. preexisting beliefs, aspirations for the program) prior to ICJ involvement to facilitate a more objective comparison. The information gathered about both preexisting beliefs and perceived changes were in the context of asking participants to reflect back, and therefore, may be colored by their experiences, knowing how the program culminated and how they benefited from it. Pre-course surveys were collected for some of the earliest cohorts for internal program use, but were gathered before IRB approval, and therefore, could not be included in the analysis.

All interviewees in this project were those who had continued to remain involved with the program post-graduation, which stands to reason that they had a favorable view of ICJ. There were participants who began the course, but who did not complete it for a variety of reasons (i.e. release, lack of interest, time constraints). It should be noted that these participants will be significantly harder to locate and contact, and it is unknown whether they would be willing to participate in an evaluation. Future analyses of program impact will necessitate the inclusion of these voices to offer a more comprehensive understanding of ICJ's impact, strengths, and weaknesses.

\subsection{Ethics}

In addition to securing approval from Columbia's IRB, I also completed the internal ethics process within the Institute of Criminology. As noted above, all participants were emailed the 
IRB-approved consent form (Appendix B) at least 24 hours prior to their interview. Once on the call, participants were led by the researcher through the informed consent process, which consisted of summarizing the study and procedures, answering any questions from participants, reminding interviewees that participation was voluntary and could be withdrawn at any time, and finally, obtaining their verbal consent. Informed consent is a required element of IRB approval. Because participants were discussing potential sensitive information (e.g.,details of their incarceration, negative experiences with law enforcement, racism, etc.), it was also crucial to continue to maintain open lines of communication with the subject during the interview to ensure that they did not feel compelled to disclose any information that they felt uncomfortable sharing.

After some discussion with CfJ staff around previous studies they have conducted, I decided to provide each interviewee with a resource sheet of local organizations that specialize in various services for formerly incarcerated people (Appendix C). In light of my interest in networks, connectivity, and community-building, it was important to engage with the practice myself in connecting those in my own network (interviewees) with additional resources. While I am not an expert in reentry, I, along with the rest of the CfJ team, have extensive experience with supporting returning students, and thus have familiarity with local reentry services. In compiling the resource sheet, I also consulted others familiar with reentry at the IIP and some directlyimpacted students.

All students were compensated with a $\$ 40$ Visa gift card for their time that was mailed to them at an address provided post-interview. As public servants, current prosecutors were unable to accept compensation. The question of compensation in research is a contentious one: "Concern exists regarding the potential for payment to unduly influence participation and thus obscure risks, impair judgment, or encourage misrepresentation" (Grady, 2005, p. 1681). Monetary payments in research are used as inducements--motivations to get an individual to do something; inducements are typically viewed as non-coercive as they constitute offers rather than threats to participate in a study (Bentley and Thacker, 2004). However, incentives can become problematic under the following circumstances: a subject who is dependent in some way to the researcher, particularly high-risk scenarios, degrading research, large incentives meant to overcome a participant's strong aversion to participation, or a combination of any of the above (Grant and 
Sugarman, 2004). Furthermore, monetary compensation for research participation may result in economically disadvantaged individuals shouldering a disproportionate amount of the risks of participating in research (Ackerman, 1989; Macklin, 1981). As per the recommendation of Dickert and Grady (1999) and Grady (2005), this study follows the wage-payment model that provides participants with a standard "wage" payment as compensation for their time and effort. This model allows participants' contributions to be recognized, creates a uniform payment, and provides less risk of undue inducement (Grady, 2005).

It is important to acknowledge my own potential biases in this research process. Prior to my enrollment at Cambridge, I was a program coordinator for three years at CfJ. I helped with the logistics and implementation of the first ICJ cohort in spring 2018 and worked with subsequent cohorts through the summer of 2019, when I left for Cambridge. This included in-facility recruitment, curriculum and enrollment logistics, class observations, and graduation coordination and planning. In sum, I am well-versed with the program and personally know several of the staff and participants. I believe that ICJ has a significant impact on those who participate-it certainly did on me. This in-depth understanding and personal connection to ICJ is a strong asset: it allows me to delve deeper and to find unexpected themes that might be missed by someone without the same knowledge base. However, throughout this process, I was constantly reflecting with myself to ensure that as a researcher, I remained as objective as possible. Indeed, good research requires continual introspection, but is it possible to divorce oneself from personal emotions and experiences, and furthermore, is that even a desirable objective? In his article "Whose Side Are We On?," Becker (1967) articulated this tension in social science, "to have values or not to have values: the question is always with us" (p. 239) and concluded that complete objectivity is impossible. Per Becker, as researchers, our dilemma lies not with the question of having allegiances, but rather to whom are our allegiances, given, understanding that research is most often undertaken in the context of hierarchical relationships. Reflecting on her own work inside maximum security prisons, Liebling writes:

[O]ur emotions do not need to be reconciled with our so-called data. They constitute data. They require critical reflection and triangulation and "faithful representation," but not 
selective inattention.... reflexivity with an ethic seems to me to provide a way of tackling the emotional dimension of research honestly and with some purpose. (1999; p. 164)

Nonetheless, "these values are in tension — but living with this complexity is a more legitimate route to take than trying to control or eliminate it" (Liebling, 2001, p. 483).

Additionally, as Dr. Kenneth B. Clark wrote in his introduction to Nature of Prejudice, "Allport and Myrdal personify the insistence that thoughtful, moral, rationalistic social scientists must be the contemporary custodians of such enduring human values as justice--and that trained human intelligence is an important weapon in the ongoing struggle against ignorance, superstition, and injustice" (Clark, 1979, p. x). He goes on to critique his peers who chose to stay clear of the battle for social justice by invoking moral relativism and quantitative objectivity: "This convenient escape, whereby some social scientists can avoid involvement in the struggle for social justice or can offer their services to those who seek to use their power to maintain the status quo, may be personally protective and 'realistic'. But it is not social science in the Allport and Myrdal traditions" (Clark, 1979, p. x). As a trained social scientist, I am choosing to employ my knowledge following Allport's tradition to prevent myself from becoming the scientist that Clark warns against. However, I recognize that my strong desire to contribute to the broader fight for social change may color my perspective in search of extrapolating something deeply meaningful that may not in fact be there. 


\section{Chapter 4: Inside the experience of ICJ: findings and discussion}

A number of themes emerged as a part of this exploratory study set beyond the original scope of the research questions. For the purpose of clarity and depth, the findings discussed here will be those that pertain to the initial line of inquiry of the contact hypothesis, resulting concrete behavioral changes, and social networks. This chapter first addresses the humanization of the "other" that occurs as a result of a contact experience through ICJ. Next, it presents evidence of action taken on an individual and professional level that was produced by the shifts in perception made by the humanizing experience. Finally, it explores the networks created by the program for each kind of participant, and discusses what happens when networks fail.

\subsection{Contact theory and humanization of the adversarial other}

ICJ's applies all four of Allport's (1979) specified conditions for intergroup contact to be successful. These conditions are satisfied via: policy proposal projects (intergroup collaboration and common goals), presence of officials at graduation and the cooperation inherent in the course's existence (institutional support), and universal learner identities, culminating in equal voice in the policy presentation at graduation (equal status). Course instructors make an effort to ensure that every participant's perspective is heard. Given the natural power imbalance in authority (prosecutors are members of law enforcement) and mobility (incarcerated students do not have their freedom), special attention is paid to elevating the voices of the incarcerated students.

To assess how perceptions have shifted, we must first establish the range of beliefs with which participants entered the program. It is crucial to note that both groups were self-selecting: many of the prosecutors were already more progressively-minded (i.e. liberal about the aims of the justice system, sympathetic to the plight of incarcerated people, aware of systemic issues) prior to taking the class, or at the very least, open to change and connection. This was a nonmandatory program for students with an educational incentive via college credits, but similarly, they had to be amenable to spending a considerable amount of time alongside prosecutors. Most participants joined for the learning opportunity, both intellectually and experientially; others enrolled out of a curiosity about the experience. Many students were looking for productive 
activities to participate in during their incarceration, as well as eager to engage with educational programming in particular.

\section{Pre-existing beliefs}

On the whole, student participants had an overwhelmingly negative view of prosecutors coming into the class, due in part to their negative personal experiences with prosecutors. Five of the seven students interviewed reported highly unfavorable views of prosecutors ranging from mechanical and indifferent at best, to manipulative and cruel at worst:

It just seemed so mechanical. Like no one cared about who you are, what you went through, why you did what you did...Everything was so black and white....Now, it's not even up to me, nothing that happens now is in my control, everything is up to them. (Student 05)

I actually thought that they were liars, to be honest, coming from my personal experience... They all knew who did what, but because I didn't help them, I kinda got punished hard. (Student 04)

Prosecutors were malicious, nasty, they were just looking to get me convicted. They would offer a plea deal automatically, just to basically close the case, not looking at the circumstances. (Student 02)

They're in a game...but they playing with people's lives....even if they lose or win, they still get to go home....So it's a dirty game that they play. (Student 07)

As per Allport (1979), the categories (i.e. prejudices and ideas of others) that we form are more or less rational and generally have their origin in a "kernel of truth". These small truths or experiences are heightened considerably when tied to a strong emotional response: "intense emotional feelings have a property of acting like sponges. Ideas engulfed by an overpowering emotion, are more likely to conform to the emotion than the objective evidence" (Allport, 1979, p. 22). Criminal justice contact can be traumatic, with consequences that can be felt from arrest 
(Geller et al, 2014) through incarceration (DeVeaux, 2013; Haney, 2002; Sykes, 1958). In many cases, the last contact students had with prosecutors was their own sentencing, a day fraught with a variety of emotions ranging from rage to despair. Thus, following Allport, the categorization of prosecutors in the minds of the incarcerated students was particularly and negatively vivid.

However, this was not true for all the formerly incarcerated people in this study. Two students had more favorable opinions of prosecutors in comparison with their other classmates. One student was able to conceptualize the role of the prosecutor as stemming from a desire to protect, something he related to in his own life:

I think that people step into those roles because they want to be some form of a protective line for communities...I can kind of rationalize that because I envisioned myself the same way, as someone who protected and provided for my family, even at a young age....you want to protect your whole community, or communities that you represent, and I want to protect my family by any means necessary. (Student 01)

For Student 01, understanding the prosecutors was, in some ways, about sharing a common goal, which as per Campbell (1965), groups that share goals are less likely to produce the level of hostility seen between groups whose goals are perceived to be in competition. He also describes a mutual identity outside of the dominant "incarcerated student" and "ADA" roles at play: they both occupy the role of the protector. In his conceptualization, while his protector role was limited to his more immediate circle, like his family, Student 01 imagined a prosecutor taking up the same mantle, but on behalf of a larger group, the community. Social identity theory also emphasizes the emotional component of social identification, often causing an individual's selfesteem to become intertwined with aspects of the group identity, especially as they begin to adopt the norms of that group (Tajfel and Turner, 1979). "Protector" is a role with significant emotional connotations. It is a role that can be a powerful and burdensome identity, echoed by Student 01 's need to serve that function "at a young age" and emphasizing the lengths he would go to in order to fulfill it ("by any means necessary"). Thus, by drawing a connection to this protector identity, Student 01 is able to appreciate both the good intent that may lead to poor 
outcomes and well as the heavy burden inherent in working to keep people safe that are parts of a prosecutor's job.

Meanwhile, another student's feelings towards law enforcement originated in the direct personal connection he had within his own circle:

They have a tough job. Just because I was locked up....I don't hate the prosecutors. I did something wrong and I needed to be punished for it....My father was a police officer, my family are police officers. My friends are police officers. That didn't change my opinion, just because I got locked up. (Student 06).

Both students' views of prosecutors as a whole were influenced in some way by their connection to an idea of family. In thinking about Allport's version of the contact hypothesis, Pettigrew (1998) suggests that friendship or acquaintanceship can be a significant contributing factor to reducing prejudicial ideas or beliefs, which is demonstrated in Student 06's response. His view of law enforcement was influenced by the meaningful relationships that he had built prior to his incarceration that were able to mitigate other negative experiences ("that didn't change my opinion, just because I got locked up"). This familiarity also occurs in conjunction with acceptance of his punishment ("I did something wrong and I needed to be punished for it"). Student 06 also takes responsibility for the actions that lead to his time in prison, and sees his incarceration (though not the conditions of it) as a just consequence for his actions. This follows Tyler's (2003) process-based regulation model that "suggests that people's willingness to accept the constraints of the law and legal authorities is strongly linked to their evaluations of the procedural justice of the police and the courts" (ibid: 284).

In examining prosecutors' preexisting beliefs, all ADA participants shared a willingness to listen and engage with divergent perspectives from their own. Almost all believed in a need for the practice of incarceration, but many were already critical of prison conditions, and overly harsh mandatory minimums. Some prosecutors came to the course when they found themselves at a crossroads in their own careers as they wrestled with their personal views of the system within which they worked. For others, the course was a natural step in an evolution process of their 
prosecutorial work towards more liberal and rehabilitative practices. To this end, many made reference to the self-selection inherent in program participation:

[B]eing a self-selecting participant of this program, I was already primed for this conversation. And I feel that most, if not all of the prosecutors who were involved were already primed on this stuff...I can't imagine someone who feels as though the system is okay as it is, I can't imagine them volunteering this amount of time. (Prosecutor 07)

Prochaska et al.'s (1992)'s stages of change model offers a useful framework in conceptualizing how individual change occurs, positing the process as a spiral with four distinct stages: contemplation (acknowledging a need for change), preparation (thinking concretely about how to make change), action (taking steps to alter behavior), and maintenance (reinforcing the behavioral change gains). Following this model, most of the ADA participants can be seen as entering the class in the "preparation" phase, the prerequisite for action. Preparation is described as a stage that harnesses intent and behavioral action, in which a person may have tried to take action and was unsuccessful, but plans to try again in the near future, originally referred to as decision-making (Prochaska et al., 1992). That is to say, the prosecutors who took this course had already given considerable thought to the way the current criminal justice system functions and their own role in it, and were eager to do something, but were unsure how to or had not acted on it yet. The model notes that successful change is contingent on recognizing where the individual is within the stages of change, and tailoring interventions to match to help them continue to advance through the process (Prochaska et al., 1992). It follows then, that a course like ICJ would likely be less impactful for those who, as Prosecutor 07 states, were not already thinking critically about the justice system and prepared to act.

While all ICJ prosecutors were relatively open-minded in their ideas about incarcerated and formerly incarcerated people, those with the most expansive and humanistic views were informed by their lived experience with directly impacted community members or loved ones. Those with some personal familiarity with the system, like Prosecutor 03 who grew up knowing several friends and family members who were incarcerated, were better able to understand the 
complexities and nuances that are involved with the decision to engage with crime, a blindspot for many prosecutors coming from more privileged backgrounds:

That's a question that most people who ended up being attorneys have never had to fucking answer, but I wonder what your answer may have been if you grew up in those circumstances and had to make that same choice so we can remove the fucking moral judgments from it. (Prosecutor 03)

A student echoed that this perceived lack of empathy on the part of prosecutors stems from a dearth of personal connection with directly impacted and/or marginalized groups:

$[\mathrm{C}]$ ause at the end of the day, most of their friends or family don't look like me. The sympathy element or the empathy aspect, sometimes doesn't play into the equation because I'm just considered an 'other', right? Them, not us. Unconsciously, you might act differently. You probably prosecute differently. (Student 04)

Much as Student 06's view of law enforcement was tempered by his friendships with police officers, so is Prosecutor 03 influenced by his relationships with and proximity to directly impacted people. In both cases, these relationships allow for a high degree of differentiation and compassion for the challenges associated with each group's status.

Other ADAs were shaped by their interactions with the community as part of their job as prosecutors. Through working with young people for over a decade and on a case that resulted in a significant number of adolescents being arrested or sentenced to incarceration, Prosecutor 12 recalls seeing the consequences of the criminal justice system on the defendant, the victim, and their loved ones and reckoning with the emotional price of prosecution:

I think even before that case was brought, I felt awful for the lack of choices that we had. Once that case was brought in, I had lived through the consequences, for those victims, for their families, for the defendants and their families, and even just reminded myself of an emotional toll that prosecuting young people can take on you. (Prosecutor 12). 
One participant had worked extensively with directly impacted community members, and as such, was acutely aware of the consequences of becoming entangled with the justice system and the complex ways in which the community intersects with incarceration:

There are many people who come and sit across the table from you as a prosecutor who themselves have had interaction the criminal justice system and have had distrust, have had the consequences of living with a criminal conviction....and I've been hearing their concerns and the aftermath of that for years...One of the children that I worked with, the person who had been her abuser pled guilty, and it was time for sentencing...She was very little, but she wrote a letter and her father came to read it for her. When I was explaining the process to her, her dad was like, 'well, you've been there when I've been sentenced.' (Prosecutor 06)

\section{Humanizing experiences}

Some form of the stem word "human" (human, humanization, etc) was used 79 times by 14 participants to explicitly describe their ICJ experience. This section discusses the varied encounters encompassed by the experience of humanization and the perception shift that occurred towards the "other" to illustrate the myriad number of ways individuals can be humanized by a contact experience.

Nearly all participants reported feeling some kind of anxiety, apprehension, or nervousness prior to walking into the classroom on the first day. This is to be expected as "the greater the distance we are from different experiences, the more it is likely to generate anxiety, fear, hostility, and anger" (Plummer, 2019, p. 67). Uncertainty about interacting with members of the out-group can trigger uneasiness, awkwardness, frustration, and anxiety (Stephan and Stephan, 1985). It would be highly unusual for the prospect of encountering the "other" not to trigger some degree of trepidation, particularly for highly adversarial groups like incarcerated people and prosecutors who so infrequently meet on neutral terms. Furthermore, ADA participants had varying degrees of familiarity with correctional facilities: some had previously been to a jail once before as part of their professional training, while others had extensive experience from working in conjunction 
with investigations. It is important to appreciate that some participants found themselves in a deeply unfamiliar environment, in addition to the anticipation of interacting with the unknown and potentially adversarial other. While students did not have the environmental factor to contend with, as noted previously, their experience was often layered with painful and traumatic memories.

Stepping inside the facility after processing, prosecutors were immediately confronted with the realities of prison life:

[Y]ou make the first turn and we saw people in a holding area, that were being made to stand back when you're walking by...it's just a quick reminder that someone is in there and does not have their liberty.... and that they want to go home and that they have family. (Prosecutor 02)

For another participant, encountering the perceived arbitrariness of the rules of the facility during processing gave her an appreciation for the challenges of living with that level of uncertainty daily:

[I]t was so infuriating because the rules change for us to get access into the prison...these rules that impact their everyday life change everyday. They often complained about that. They're just sort of at the whim of the corrections officials, and the corrections guards to change the rules up on them. (Prosecutor 10)

Many participants recounted the value of the initial ice-breaker exercises--described by several as "speed-dating"-- on the first day of class as a means of breaking down barriers. All participants sit in a circle, alternating the seating arrangement to prevent a retreat to their own groups and subsequent reinforcement of existing in-group boundaries. All classmates paired up to answer a series of "getting-to-know-you" questions (e.g., favorite food, TV show, etc.) for two minutes and then rotated around the circle, ensuring that everyone interacted, even briefly: 
[O]nce everybody started talking, you actually realize that they're human. [Laughs]. And in a lot of cases, we had things in common, like music, movies or whatever...so, you realize everybody just wants the same thing, which is prosperity, success, safety, the basic human elements. (Student 04)

One prosecutor who later also taught the course stressed the value of these ice-breakers that seemed innocuous to help set the culture of the course:

You couldn't even jump into the readings until everyone has talked about like, what's your favorite TV? It's good just having that, just gotta put everyone on the same level. So that's an overlooked part of it, but I think you have to form the group identity before you can do anything. (Prosecutor 05)

Part of Allport's theory stresses the ideal of equal status in order to optimize the result of the exposure. Questions like those in the icebreakers center on learning about the mundane and the everyday things that we all do, information and conversation that is so often denied to these particular actors. It begins to break down the hierarchical norms that Allport (1979, p. 488-9) cautions can undo the benefits of the experience.

Having the opportunity to collaborate with students and get to know their stories reiterated the importance of seeing each case individually. One prosecutor, who got to know a student with multiple violent convictions, acknowledges the nuances that their criminal record may not provide:

If I saw her on paper, I'd think, wow, this is a person that has made some bad decisions. But, knowing her in real life, I'm like, she just made some really bad judgment calls. She's not a bad person, she just made some really stupid decisions. She really wants to make her life better. She doesn't want to go back to prison, she wants to do positive things in her life. (Prosecutor 10) 
In looking at case files, a defendant, particularly one who has had repeated contact with the system, can be reduced to a long list of charges and convictions. As Prosecutor 10 highlights, without knowing the underlying circumstances and motivations behind each charge can elevate the perceived risk that an individual presents. This, in turn, may lead to the prosecutor advocating for hasher measures (denial of bail, longer sentences in plea deal offers) rather than addressing the issues at the heart of the behavior that may center around a variety of environmental factors (e.g., substance abuse, poor judgement skills, domestic violence, etc).

One aspect of the course also involves a personal change project using the Prochaska et al. (1992) model, where each participant chooses a habit (e.g. getting up earlier, eating more healthy food, working on active listening) to change and works on it for the duration of the course. At the end of the course when all participants shared their experiences of trying to change, many ADAs and students were striving for similar goals:
You would think maybe that they live such different lives, that they wouldn't have the same kinds of projects, but a lot of them were the same. The ones that I'm remembering now are ways of treating people with more kindness or approaching difficult situations...I'm sure they felt some kind of bond just because they were having similar problems in different places. (Prosecutor 13)

Indeed, formerly incarcerated people share many of the same goals as their non-justice involved peers: the most common long-term goals for returning individuals include the establishment of a career, educational achievement, the ability to financially support their children, and the desire to have a "normal life" (see also Helfgott, 1997; Shapland and Bottoms, 2011). Working on the personal change project reaffirmed that all participants have similar aspirations rooted in basic needs, and that everyone has something to improve upon. It was a reminder of mutual imperfections and the ongoing struggle to transform ourselves into the best version of our potential. The process of change is ongoing throughout the life course, and is a difficult one at that. The perceived wide chasm between "them" and "us" began to narrow when participants were able to realize that at their core, they were more alike than different, especially with some of the challenges they confronted on their journey to personal growth. As Prosecutor 13 notes, 
these conversations provide a bridge to build bonds, a sentiment echoed emotionally by Student 05:

[T]here's people from that classroom that if I ever saw them in the street, I would hug them...Right now I feel like I'm about to cry...I know it was a connection with some of those people and that's something that definitely helped me coming home because it doesn't matter where we're from, what we've been through. We can all have the same goal. (Student 05)

For one participant with ties to a directly impacted community, connecting and forging friendships with students inside offered a chance to connect with people who reminded him of long-lost childhood friends:

Unfortunately, I ended up on a trajectory that was very different from theirs and have lost contact with many of them [childhood friends], which is sad for me in a lot of ways. Being able to spend time with [student] felt deeply familiar in ways that I really missed. (Prosecutor 03)

The student mentioned above had a reciprocally strong connection with the prosecutor, and recounts a story of meeting up with him shortly after his release:

I saw him as someone who could be like my big brother. When I was released, he invited me to his house, to help him paint. I had just come home from prison, he had just met me a few weeks ago in this course. He was a prosecutor, but he wasn't afraid of having me as a felon around him and his family, made me feel welcomed. I appreciated him....it was really him that made me see them as people who had families, who had lives, who had other responsibilities outside of the courtroom. (Student 01)

One can even see this bent towards humanization in the language that the prosecutors used to describe their classmates: nearly all of them (12) consistently referred to the formerly incarcerated participants as "classmates," "peers," "friends," and "students". 


\section{Limitations to humanizing encounters}

It should be noted that there are certainly limits to this process of humanization. While students had a positive view of the prosecutors that they worked with, many maintained a negative view of the system as a whole. Understandably so, an eight-week course could not undo years of trauma and pain that shaped their views of the justice system more broadly:

These are the things that we need to ask as a society: is a person in there to get punished or is he in there so he could rehabilitate and become a better, productive citizen? Which one is it?....nobody has never, ever asked me in 20 years, am I okay?...Is sending a person away for whatever amount of time, is that justifiable?...you gotta just look at the whole system and be like, is it worth it? (Student 04)

In some cases, the course not only solidified these negative views of the system, but amplified them:

Because the things that I know now, I didn't know before, so my thoughts of the system are worse, but my thoughts of the people involved in the system are better... It still frustrates me. It makes me upset. It does make me want to get out there for social change...There's so much, we're being brainwashed into just not being really successful or always being at a disadvantage. (Student 05)

The student maintains a favorable view of his ADA peers, but learning about the systemic failings of the justice system from an academic vantage point fomented preexisting ideas. Interestingly, the student emphasizes agency. Despite learning about the numerous disparities associated with the criminal-legal system, rather than making him feel helpless, this knowledge made him passionate about taking action. For another student, while it was helpful to have conversations with ADA participants in an attempt to understand their perspectives both personally and professionally, that bond felt superficial outside of the classroom: 
It's like a fake bond....you can't tell if they're full of shit. I feel like most of the people that were in jail were speaking from the heart in some ways or another....I could see some reservation behind the ADAs, except for like two....they don't want to admit what they're doing is wrong, but we're having to admit what we're doing is wrong. (Student 03)

Student 03 suggests that even though the course does its best to create a neutral classroom environment that values all participants equally, unequal power dynamics can still persist beneath the surface, especially around vulnerability and disclosure, which, in turn, impacts trust. Indeed, social relationships are at their strongest when they are firmly rooted in trust (Fukuyama, 1995) and reciprocity (Coleman, 1990, Kolm, 2000). It is a reminder that even when a situation is thoughtfully engineered to serve as a neutral and collaborative space, the reality of the world beyond the classroom still seeps in.

\subsection{Translating insight into concrete action}

Exposure helps to humanize, but does it translate into participants taking action to work for change? In the case of this sample of ICJ participants, the findings indicate that there is a strong relationship between humanization and action. To varying degrees, change occurred at both the individual level and the institutional level.

\section{Individual behavioral changes}

On an individual level, it seems that ICJ helped ADA participants consider their approaches to their work, and inspired them to make modifications in response to what was shared by their formerly incarcerated peers. This included using humanizing language in court, increasing referrals to the alternatives-to-incarceration unit, considering shorter sentence lengths, and implementing restorative justice practices. These new approaches are consistent with the hypothesized behavioral changes that were centered around actions related to dealing with defendants or incarcerated people (e.g., recommending lower sentences, charging less felony cases). It was also theorized that ICJ would produce increased involvement in social justice causes relating to mass incarceration (e.g., going to events and trainings on aspects of mass incarceration, engaging friends and family in discussions about these issues, etc). 
Returning to Prochaska's model, subsequent action post-ICJ can be classified as "maintenance" where individuals strive to "consolidate the gains attained during action. Traditionally, maintenance was viewed as a static stage. However, maintenance is a continuation, not an absence, of change" (Prochaska et al., 1992, p. 1104). Change is something that must continually and actively be practiced; even once a change has occurred, keeping it that way is a dynamic process that requires commitment and ways to regularly practice and affirm the change. Hearing her classmates' experiences in court convinced one prosecutor to change her approach in court immediately, in a small but meaningful way:

Something that some of the guys mentioned in our classes was that the prosecutors don't look at them [in court], don't call them by their name, so I immediately started doing that. It makes a difference, not just to them, but to me, as I treat somebody like a human being... you see them as a human being much more, you SEE them. (Prosecutor 01)

Using a person's name is an affirmation of their individual identity, and by extension, humanizes them beyond a case number or one task in a long day of court appearances. This minor courtesy has a reciprocal humanizing effect: it allows the person in court to feel seen while forcing the prosecutor to recognize them as the individual that they are. This is a key demonstration in the principle that language matters. The words we choose and how we employ them are a reflection of who we are, our social relationships, and our worldviews: "Language is the most common and reliable way for people to translate their internal thoughts and emotions into a form that others can understand" (Tausczik and Pennebaker, 2009, p. 25). Using a person's name then signals that the prosecutor recognizes and affirms the justice-involved individual's right to humanity.

Others mentioned consciously referring cases to the alternatives-to-incarceration unit, which uses a holistic process to assess and understand the individual charged with a crime to determine a potentially more rehabilitative solution than a prison sentence. The course affirmed the need for more information about each person before serious decisions are made: 
This is one of the only times I've really gotten insight into what the person charged with the crime, or in this case, convicted of the crime is really feeling. And frankly, it's a lot more important to have that insight prior to the conviction. (Prosecutor 08)

Participants with more seniority also used the ICJ experience to work towards ensuring fairness in the cases being handled by their subordinates:

When we dispose of cases and someone comes in and suggests a [sentence length], I ask why, it's my auto-immune response now....I want to know how you got there, what comparisons you did and why you think that this amount of time for this person, this human being is necessary. (Prosecutor 02)

Consistent in all three accounts above is a continuation and implementation of the humanizing narratives prosecutors acquired in ICJ to shape some of their professional decisions, and in the case of Prosecutor 02, those of colleagues as well.

While ADA participants reported some degree of impact on their behavior, it appears that the opposite was true for the formerly incarcerated individuals: a small minority (two students out of seven) reported that the course had an impact on their actions. One student indicated that ICJ allowed him to handle an interaction over an expensive parking ticket with a new prosecutor in traffic court differently. After sharing with her that he had recently come home and was trying to get back on his feet, the ADA agreed to lower the fine, but could not dismiss the ticket. Rather than being upset, the student was able to have empathy because he was more familiar with the limitations of her job: "I mean the Inside Criminal Justice class, I was able to kind of see her hands were tied. That gave me a perspective of her point of view" (Student 04). He attributed the course with giving him a new attitude: "I definitely look at district attorneys in a whole different light. I actually realized that some of them do care...They're just...doing the best that they can with what they're given" (Student 04). He was able to recognize that the prosecutor handling his case in traffic court was similarly doing the best she could, which then allowed him to react differently, even when, in this case, receiving a less than ideal outcome. 


\section{Large-scale actions}

On a broader scale, some of the policy proposals introduced at graduation have come to fruition. This has included the creation of a computer lab at one of the facilities specifically to help students gain employment skills and a Department of Motor Vehicles office at one metropolitan Office of Parole where returning citizens can get state forms of ID. An ADA ICJ working group has been formed within the office where alumni can continue to connect, share ideas, and work towards implementation of the joint policy proposals. There was an expressed need to create a more systematic way to review and implement the policy suggestions in a meaningful and tangible way (see Appendix D for practitioner-based considerations), for example, using a process more akin to grant applications where proposals are reviewed by a designated committee who can solicit more information and follow up as needed.

There is also momentum within the DA's Offices to try to make some form of ICJ mandatory for all staff members, with the hope that the course will help all prosecutors, regardless of level of experience, to think differently about the decisions they make daily. All ADA participants and the majority of student participants expressed a desire or need for some form of ICJ to be mandatory for all prosecutors. However, as noted by three interviewees, there are some important considerations that should be given to how participants are recruited to prevent a potentially detrimental encounter and to ensure mutual respect and trust (see Appendix D).

Participants have also used the ICJ model to develop their own programs for young people and for reentry issues in the Tri-State Area. One participant was inspired by his ICJ experience to ask, "why are we waiting for people to go to prison...before we give them an opportunity to be in close proximity with people who work for government and also be in a position to advocate for policy changes within governing institutions?" (Student 01). He subsequently adapted the program model to a different demographic. His program follows ICJ's structure, but focuses on young people and city officials, rather than prosecutors and formerly incarcerated people.

One participant credits the decision to pursue a restorative justice solution in a serious violent crime case to the ICJ experience: "Our office has never done ANY restorative justice on any level...that was directly from stuff that I had read in the class...and what we talked about" 
(Prosecutor 01). Doing so required her to stand her ground, even when she faced disapproval from colleagues:

I was really torn about what to do about [the case], and I got a lot of pushback in my office. I've kind of put my career on the line for it....at one point they were like, 'if you don't agree with the way we want to handle it, you could step off the case.' And I was like, 'Nope. I'm not gonna do that. I'm going to make sure that we do the right thing in this case.' And it ended up being really successful. (Prosecutor 01)

Because of its success, Prosecutor 01 said her office has asked her to lead in-office training on restorative justice for other ADAs with the hopes that more prosecutors will consider pursuing similar outcomes.

\subsection{Network expansion and collapse}

The question of networks was addressed in two ways in the data: networks that were formed as a result of the course that could be mobilized for change and endowed participants with a new layer of credibility, and the absence of networks and support that contributed to individual challenges and wider, more systemic failure within the criminal-legal system at large. While network creation was not an explicit goal of ICJ, it occurred as a natural by-product, as did conversations about network collapse through sharing experiences about paths to incarceration.

ICJ created a network that offered its participants a type of credibility that was valuable to them in some way in their life beyond ICJ. For the students, the personal became professional as they gained connections that both affirmed their transformation and could be leveraged to make change in their communities; and for the prosecutors, the professional became political as they acquired proximity to the human cost of the decisions they make and the power their position holds.

\section{Affirmational credibility}

For some students, engaging in ICJ brought what could be deemed as "affirmational credibility": a representation, affirmation, and confirmation of the change and self-growth they had made 
during their incarceration. The networking-building that occurred in the course was symbolic of the steps that students were taking on their journey of self-improvement:

[T]hese are new relationships that I've formed....and that I felt that I wanted that to continue because I knew that they will be more in line with the type of person that I wanted to be as opposed to my old association, to completely the opposite of what I have become, of who I am. (Student 02)

In part, reentry can be conceptualized as a process of rebuilding identity. Maruna's (2001) narrative identity theory of desistance examines the process of identity reconstruction of stigmatized identities through "narrative repair", allowing formerly incarcerated people to change and lead productive lives through discovering evidence of their own moral agency and recrafting negative experiences as redemptive suffering. The "helper" or "wounded healer" identity has been associated with higher self-esteem, greater satisfaction with life and a strong predictor of a non-criminal attitude and rearrest (LeBel, 2007). Maruna et al. (2004) argue that rehabilitation begins to happen when motivations based in generativity become internalized through social interactions in settings that define such behavior as "good". They note that correctional environments seldom provide this kind of setting that would be most conducive to rehabilitation. However, one might suggest that ICJ creates this kind of environment within the prison space, and by extension, creates a network based on a foundation in generativity that will continue to reward such behavior, and thus, rehabilitative progress, on the outside. The network created by ICJ is meant to transition with the student to the outside as they reintegrate.

ICJ also represented access to individuals that students felt had the power to make change and as a means to continue to push for resources that would be meaningful in their communities:

Now I have access to individuals who I can actually speak to, to help promote and push certain agendas that serve the community and that help the youth. These relationships, I think, are really important for that reason and to give voice to a lot of the things that concern us, which we will not be able to do without these connections. (Student 02) 
As Wolffe and Draine (2004) propose, “a prisoner's social capital is embedded in social relationships. The productivity of social capital as a bridging resource depends on the number and strength of these social relations and their resource endowments" (ibid: 469). Social capital, as defined by Fukuyama (2000) are informal norms promoting cooperation ranging from reciprocity between friends to complex religious doctrines, but " $[\mathrm{t}]$ hey must be instantiated in an actual human relationship: the norm of reciprocity exists in potentia in my dealings with all people, but is actualized only in my dealings with my friends" (p. 3). That is to say, social capital exists in a theoretical realm until it is manifested through authentic relationships.

As is evident above, because of the connections that ICJ offered, students felt as if they could serve as a bridge between law enforcement representatives and their fellow community members, or as a microphone, amplifying the voices and concerns of their community members who lacked ties to public officials. Many formerly incarcerated people come from impoverished neighborhoods that are disproportionately impacted by mass incarceration, the stigma of which weakens both human and social capital (Clear et al., 2001). These communities are often underresourced and ignored by government officials. Student 02 sees himself as being an agent of change working to alleviate some of his community's struggles by advocating in spaces where they do not traditionally have a seat at the table.

Community prejudice towards and misinformation about formerly incarcerated people represents one of the largest barriers to reentry success (Helfgott, 1997). Being incarcerated results in social disapproval and rejection, which can trigger larger questions about identity: "The social isolation itself raises questions for ex-prisoners about their very place in society and whether they belong....In particular, how do I, as an ex-prisoner, define myself and how do I let others define me?" (Mears and Cochran, 2015, p. 128) This awareness of the social stigma of incarceration and an active attempt to redefine oneself through actions in the present was discussed by one student in sharing his experiences of reentry:

That right there is something I'm very cognizant about. I'm representing myself and my family name....I would never want to be the type of person where they'd be like, isn't that 
[ICJ instructor] friend? I wouldn't even want to embarrass her like that, or anybody that's involved, you, anybody that's involved with our plight. (Student 04)

Notably, he highlights a concern about a potential transference of the negative stigma onto those who have helped him because of their involvement with him. In some ways, this might be construed as not only a desire to protect himself, but also to maintain the integrity and respect of the network that he has built around himself. Not only was this student trying to redefine his own definition of self through his actions, but in essence, also working to define and preserve the reputation of those connected to him. There is a clear understanding here of access to the network as an earned privilege. The network also serves as motivation to continue on a positive trajectory: to work to give others a reason to be proud to include him. As posited by the belongingness hypothesis and affirmed by empirical support, "the need to belong is a powerful, fundamental and extremely pervasive motivation" (Baumeister and Leary, 1995, p. 497). Indeed, strong social bonds and access to social capital are thought to be key in successful reentry (Wolff and Draine, 2004), acting as informal controls against broader societal influence to help individuals move away from illicit behavior (Sampson and Laub, 1993, 2003).

Much in the way that classmates grow and evolve together in their ideas about the justice system, so they are also able to continue that process interpersonally once the course has finished. In many ways, certainly for the students, the ADA participants are part of their journey, perhaps in an even more salient way because of their appearance amid the transition back home during their final days of incarceration. In the case of students, the networks that they created through ICJ were indicative of the tangible steps they were taking in their rehabilitation, as well as a way to continue to redefine themselves positively, and a source of pride and motivation to keep striving on their journey of reentry.

\section{Community credibility}

By participating in ICJ, ADA participants gained a personal understanding and tangible ties to the human cost of incarceration; in other words, they earned an experiential understanding. Through their interactions and relationships with students in the class, prosecutors felt that they had acquired some kind of credibility because of their connection and proximity to impacted 
individuals, similar in many ways to the idea of what is colloquially known as "street cred", but here will be called "community credibility".

Many prosecutors expressed sentiments of wanting to "serve as ambassadors on behalf of those that were incarcerated to our colleagues" (Prosecutor 02). Four participants explicitly applied the language and concept of "credible messengers" to themselves and other ADA ICJ alumni. Eddie Ellis is credited with first using the term "credible messenger" in the 1980s to predict the return of formerly incarcerated people to their neighborhoods "to reach a generation of young people whose elders had been lost to incarceration" (Austria and Peterson, 2017, p. 4). The idea of credible messengers is most frequently used in the context of violence prevention, most notably in the Cure Violence Model that requires the use of credible messengers acting as "violence interrupters" as a component for implementation (Cure Violence Global, 2019). Having a person with lived experience intervene during a "teachable moment"—defined as moments when individuals are especially responsive to interventions that then promote positive behavior change (Purtle et al., 2013) — can have profound impact (Webster, et al., 2012; Wical et al., 2020). Prosecutors extracted this idea of someone with lived experience being able to intervene with their peers to prevent harm (in this case, perpetuation of unjust prosecutorial practices), and applied it to their own office culture. The essence of this credible messenger-style prosecutor is best described by Prosecutor 08:

As people who have gone through this program, we have an obligation to spread the word of what the incarcerated individuals in our cohorts were sharing with us.... I feel like we need to be the credible messenger, so to speak, of our own within the office....ultimately to go back full-circle to how I became involved in this, that was really what it took, was just hearing sort of a testimonial from somebody. (Prosecutor 08)

To that end, the majority of participants also expressed a desire to see the program implemented in some kind of mandatory form for the entire office to transform both the culture of the office as well as have an impact on prosecutorial decision-making. Eight of the ADAs mentioned that ICJ allowed them to find "like-minded" colleagues, which, in turn, caused them to feel less isolated 
in the office because of their more liberal ideas about criminal justice reform, and to be emboldened to voice those ideas openly within their professional environment.

\begin{abstract}
Absence of networks
Discussions about making change within the justice system facilitated many conversations about how networks fail individuals at various different points, and how to ensure that networks work collectively to support a holistic view of development, especially those in marginalized communities. Participants, both prosecutors and students alike, cited lack of information as a key frustration. Whether it was about individual cases or about community resources, many policy proposals attempted to help resolve this disconnect, ranging from placing iPads in holding cells to ensuring positive programming is better advertised in marginalized communities. Three students mentioned that they wished they could have experienced a course like ICJ earlier in their lives or learned about the justice system in a structured, academic way when they were adolescents. For that reason, they advocated for something similar to be offered to young people, in the hopes that it could play a part in preventing some of the negative choices they themselves had made.
\end{abstract}

This idea is part of a significantly larger conversation around building a more encompassing idea of what the justice system means: that is to say, that justice system involvement does not begin at the time of arrest and finish the day an individual walks free through the prison gates. Issues that lead individuals to engage in law-breaking behaviors often have their origins much earlier and in much larger entities. For example, for Merton (1938) crime is generated as a result of a socially fostered state of discontent and deregulation in a society that promises equal opportunity for success to all, but in practice, denies it to individuals through barriers like racism and classism that negate the myth of openness and possibility. This idealized "American Dream" creates pressure to succeed that consequently requires those facing such barriers to take illegitimate routes to achieve societally defined success (Merton, 1957). Research has also found robust support for the "victim-offender overlap," the connection between exposure to trauma, chronic victimization and involvement in crime (Berg and Loeber, 2011; Jennings et al., 2012; Sampson and Lauritsen, 1994), and is seen in the high rates of childhood trauma in incarcerated people (Harlow, 1999; Wolff et al., 2009; Wolff and Shi, 2012). Low-income, urban communities have 
elevated rates of trauma and post-traumatic stress disorder (PTSD) (Breslau et al., 1991), as well as incarceration rates (Rabuy and Kopf, 2015). Urban youth that are exposed to high levels of community violence may develop the perception that violence, injury or death is inevitable, known as terminal thinking (Bell and Jenkins, 1993). This is to say that crime or criminogenic behavior does not occur in isolation, but is inherently tied to the life, environmental, and social circumstances in which individuals find themselves. The criminal justice system itself is a network whose reach and whose potential prevention lies in intervention far sooner and for far longer than just when an individual is in custody.

The Bronfenbrenner bioecological model of human development proposes that an individual's development throughout the life course is shaped by all different aspects of their environment as divided up into five interacting systems: from interactions in their immediate surroundings (microsystem) to socio-historical circumstances (chronosystem) (Bronfenbrenner, 1994; Bronfenbrenner and Morris, 2006). The Bronfenbrenner model held special resonance for several students. As described by one ADA:

It really spoke to a lot of them because they've all had various factors, whether it's a family situation or the community around them or a bad partner or something that is negatively impacted them in a way and maybe clouded their judgment or led them to make a decision that maybe they wouldn't have made otherwise on their own... it led to a lot of really interesting discussions and personal stories. (Prosecutor 10)

The Bronfenbrenner model not only captured the complexities of students' own experiences that ultimately led to their incarceration, but illuminated how many factors interact and impact each other at a variety of levels. It allowed them to see their own place within a web of circumstances, some beyond their control, that helped contextualize the path that they took, and served as a catalyst for discussion and personal narratives. What is key about the Bronfenbrenner model is that it centers on layers of intersection and connectivity: at best, how positive events or behaviors can have a ripple effect, but at worst, how a breakdown in one system can transfer or even be magnified in others. Under Bronfenbrenner then, it is apparent why maintaining the networks within these systems is so critical because of its reverberational effects. Indeed, "Laub and 
Sampson portray the process not as a grim and inevitable descent into criminality, but as a sequence of events and actions which is influenced by the capacity of people to interpret and choose how they will respond" (Rock, 2017, p. 33). An individual's capacity to respond is contingent on what resources are available to them. Our understanding of the criminal justice system, its processes, actors, and consequences, should be couched in a larger ecological framework to not only understand impact, but to holistically evaluate where, when, and how the system fails and how to best rectify it in context with its connections to its interactions with other networks.

However, even networks designed with the best intentions can unknowingly create barriers if they fail to account for everyday struggles of those with whom it is most trying to engage. ICJ attempted to maintain community bonds by organizing events for participants to meet outside the context of the course. A student described being invited to events post-graduation, but how this generated frustration:

I just didn't have the time or even if I had the time, I have these four kids... when I came home, I'm coming home to bills. Everything was just trying to catch back up to where I had left off at [before incarceration]. Even though I wanted to go to a lot of the things they invited me to and would love to participate, it was just like, yo, that shit don't pay. (Student 07)

As this student highlights, individuals reintegrating back into society following incarceration are constantly balancing a myriad of demands on their time, including social, financial, and supervisional (i.e. meetings with probation or parole) obligations. As mentioned before, when considered with the lens of Maslow's (1954) hierarchy of needs, desire for aspirational needs will always be outweighed by the functional needs of basic levels of security. For many returning people, a significant amount of time, both in time and effort, must be devoted to fulfilling these needs, like employment, particularly when stigma (Pager, 2003) are at play. Those activities that are not imperative or connected to survival are suspended until those needs are met. In other words, when constructing networks of our own around engaging and supporting justice-impacted people, it is important to equally consider both inclusion and accessibility. This can take a 
variety of forms, from providing travel stipends, including students as paid speakers at events, or, increasing ways for participants to engage digitally (i.e. holding alumni group meetings with a Zoom option to ease the travel burden). 


\section{Chapter 5: Future directions and concluding thoughts}

In summary, this dissertation presents evidence of the impact of ICJ on its primary participants, prosecutors and incarcerated students through a qualitative data analysis of 21 semi-structured interviews. ICJ appears to facilitate a process of humanization by providing a space where participants can appreciate each other's strengths through working on collaborative tasks, learn individual stories through formal and informal class discussion, and as a result, shift their perceptions of each other. The strong relationship between humanization and action produced change on individual and professional levels; however, this was more applicable to ADA participants than student participants. Finally, ICJ created networks that gave its students "affirmational credibility" and its prosecutors "community credibility". The course also generated dialogue about how network failure (i.e. environmental factors and resources) contributes to justice involvement; understanding how people become entangled with the criminal justice system then requires an expanded concept of the reach of the justice system, beginning much earlier than arrest and continuing long after release.

\section{Future directions}

One prominent theme that surfaced during the course of conducting and analyzing these interviews was that of reentry. While not one of the original target areas, it was a frequent and important topic of conversation among interviewees. Reentry was touched on in discussions of humanization and network-building for formerly incarcerated students, but there are still larger questions about the intersection of the reentry and ICJ experiences. What role does the experience of reentry or narratives of reentry play in the impact of a program like ICJ? A few participants indicated a desire to hold ICJ at state prisons with individuals who were not necessarily approaching their release date. How would this change the dynamics of the program, if at all? In the same vein, participants discussed all the facilities as being distinct from state prisons because of their focus on reentry or short sentence length.

Another rich area for exploration lies in participants' conceptualization of justice. All interviews concluded by asking participants, "What does justice look like?”, which has been a CfJ programming theme since fall 2018, when staff began collecting community responses to the prompt as part of an arts festival. Ideas about what does (or does not) constitute justice were also 
elicited by participants' reflections on their own personal experiences with the system, and in thinking through the changes they would make to the behemoth that is the US criminal-legal system. Questions of racism and classism also appeared frequently in tandem with ideas about justice.

The themes mentioned above will continue to be explored as part of the next phase of research in this ongoing project. I will also be working with $\mathrm{CfJ}$ to compile some program recommendations based on the interview data.

Prosecutors and incarcerated students are one of the many tense relationships that constitute the US criminal-legal system. Other actors with similarly combative interactions can include: families of the defendant and families of victims, police officers and community members, judges and incarcerated people, corrections officers and incarcerated people. Each of the aforementioned pairs has its own dynamics and inherent challenges to overcome, but as is the case with the original ICJ target group, these individuals infrequently interact outside of negative situations or environments (i.e., court hearings/trials, arrests, correctional facilities). There has been expressed interest in expanding the ICJ program within DA Offices' as previously noted, as well as to other jurisdictions, but a thoughtful adaptation of the ICJ model could perhaps achieve similar results for these other actors. Victim-offender mediation uses a contact encounter, yet it does not have the educational component that ICJ offers, which helps to establish a common goal and equal status, and affirms the expertise of each involved party. Would ICJ be similarly effective if piloted with these other groups?

\section{Concluding thoughts}

ICJ's mission and model is particularly salient at this moment in the US as tensions between law enforcement and community members are reaching a boiling point. Protests around the wrongful deaths of Breonna Taylor and George Floyd erupted across the US in the spring of 2020 (Taylor, 2020). Much of this anger was fueled by local prosecutors delaying or declining to charge police officers involved in these civilian deaths with homicide. Prosecutors' limited action (if any) in these cases seemed to signal the state's lack of accountability for law enforcement juxtaposed with the historically heavy prosecution of low-level drug crimes that disproportionately affected 
people of color, as seen in the ramifications of the War on Drugs (Alexander, 2012). This corresponds to a feeling that the system is fair to some but not all, especially along the lines of race (Hurwitz and Peffley, 2005; Morin and Stepler, 2016).

Researching ICJ also firmly emphasized the large structural barriers that can prevent success, despite positive programs like ICJ. As noted previously, ICJ cannot undo years of systemic failure. Perhaps the most illustrative example of this is ${ }^{4} \mathrm{Nathan}$, an ICJ student who upon release had a job and was taking college courses when he was arrested on a serious violent charge. Soon after, it came to the attention of the program that he was having issues in his neighborhood around an incident preceding his incarceration and feared for his safety. Nathan was a younger student who was particularly energized and motivated to make positive change in his life. However, this desire for change did not alter the reality of the world that he was living in: prohibitively expensive housing costs left him no choice but to live at home while he got back on his feet, placing him in a hostile environment where he was constantly anxious about his safety. Nathan's reincarceration was not due to a lack of motivation or of effort to change his life, but because his circumstances vastly restricted his ability to be successful in doing so. Another student passed away shortly after completing the program following a long struggle with substance use. In a poignant op-ed following his death, former ADA Lucy Lang wrote, "Eight months after Emmanuel was released, I was in a funeral home, his brother's young children holding hands in the row in front of me" (Lang, 2019). She goes on to describe Emmanuel's numerous attempts to turn his life around, and the countless roadblocks he met along the way as he tried to rebuild his life after his incarceration: "His family doesn't know precisely when his frustration turned to despair, and his despair turned to heroin. I do know, though, that the web of systems re-entering [individuals] rely on failed Emmanuel as they fail countless others every day because they do not work together to effectively care for people" (Lang, 2019).

With the arrival of COVID-19, ICJ has been temporarily suspended, as have most in-person programming in prisons in the Tri-State Area. It is unclear when ICJ will be able to resume classes inside. However, its future appears promising, due in part to the legacy of its graduates who, as this dissertation has shown, have continued to propagate the spirit of ICJ in a number of

\footnotetext{
${ }^{4}$ Name has been changed
} 
ways. It can elevate self-esteem, trigger thoughtful introspection, shift perceptions, and serve as a building block for positive networks. Preliminary evidence offered here supports the idea that this program does work, and as more participants graduate from the program, the more ripple effects will manifest themselves in the communities of ICJ alumni and beyond. 


\section{Reference List:}

Ackerman, T., 1989. An Ethical Framework for the Practice of Paying Research Subjects. IRB: Ethics and Human Research, [online] 11(4), p.1. Available at:

<https://www.jstor.org/stable/3564170> [Accessed 15 September 2020].

Alexander, M., 2012. The New Jim Crow: Mass Incarceration In The Age Of Colorblindness. New York: The New Press.

Allport, G., 1979. The Nature Of Prejudice. 3rd ed. New York: Basic Books.

Alliance for Safety and Justice, 2016. Crime Survivors Speak: The First Ever National Survey Of Victims' Views On Safety And Justice. [online] Oakland, CA: Alliance for Safety and Justice. Available at: <https://allianceforsafetyandjustice.org/wpcontent/uploads/documents/Crime\%20Survivors\%20Speak\%20Report.pdf> [Accessed 15 June 2020].

Austria, R. and Peterson, J., 2017. Credible Messenger Mentoring For Justice-Involved Youth. The Pinkerton Papers. [online] New York: The Pinkerton Foundation. Available at: <https://cmjcenter.org/documents/Pinkerton_Papers_credible_messenger_monitoring.pdf> [Accessed 4 September 2020].

Baumeister, R. and Leary, M., 1995. The need to belong: Desire for interpersonal attachments as a fundamental human motivation. Psychological Bulletin, [online] 117(3), pp.497-529. Available at:

<https://ezp.lib.cam.ac.uk/login?url=https://search.ebscohost.com/login.aspx?direct=true\&db=pd h\&AN=1995-29052-001\&site=ehost-live\&scope=site > [Accessed 31 August 2020].

Beale, S., 2009. Prosecutorial Discretion: Introduction. Ohio State Journal of Criminal Law, [online] 6(2), pp.367-368. Available at:

<https://kb.osu.edu/bitstream/handle/1811/73071/OSJCL_V6N2_367.pdf> [Accessed 20 September 2020].

Becker, H., 1967. Whose Side Are We On?. Social Problems, [online] 14(3), pp.239-247. Available at: <https://doi.org/10.2307/799147> [Accessed 23 August 2020].

Bell, C. and Jenkins, E., 1993. Community Violence and Children on Chicago's Southside. Psychiatry, [online] 56(1), pp.46-54. Available at: <https://doi.org/10.1080/00332747.1993.11024620> [Accessed 8 September 2020]. 
Bentley, J. and Thacker, P., 2004. The influence of risk and monetary payment on the research participation decision making process. Journal of Medical Ethics, [online] 30(3), pp.293-298. Available at: <https://www.ncbi.nlm.nih.gov/pmc/articles/PMC1733848/pdf/v030p00293.pdf> [Accessed 15 September 2020].

Berg, M. and Loeber, R., 2011. Examining the Neighborhood Context of the Violent OffendingVictimization Relationship: A Prospective Investigation. Journal of Quantitative Criminology, [online] 27(4), pp.427-451. Available at: <https://doi-org.ezp.lib.cam.ac.uk/10.1007/s10940-0119129-7> [Accessed 10 September 2020].

Breslau, N., Davis, G. and Andreski, P., 1991. Traumatic Events and Posttraumatic Stress Disorder in an Urban Population of Young Adults. Archives of General Psychiatry, [online] 48(3), p.216. Available at: <https://jamanetworkcom.ezp.lib.cam.ac.uk/journals/jamapsychiatry/fullarticle/495250> [Accessed 10 September 2020].

Bronfenbrenner, U., 1994. Ecological models of human development. In: T. Husen and T. Postlethwaite, ed., International encyclopedia of education, 2nd ed. Oxford: Pergamon Press/Elsevier Science., pp.1643-1647.

Bronfenbrenner, U. and Morris, P., 2006. The bioecological model of human development. In: W. Damon and R. Lerner, ed., Handbook of Child Psychology: Theoretical Models of Human Developmen, 6th ed. [online] Hoboken, NJ: Wiley, pp.793-828. Available at: <https://doi.org/10.1002/9780470147658.chpsy0114> [Accessed 1 July 2020].

Broockman, D. and Kalla, J., 2016. Durably reducing transphobia: A field experiment on doorto-door canvassing. Science, [online] 352(6282), pp.220-224. Available at:

$<$ https://science.sciencemag.org/content/352/6282/220> [Accessed 17 September 2020].

Bruffee, K., 1995. Sharing Our Toys:Cooperative Learning Versus Collaborative Learning. Change: The Magazine of Higher Learning, [online] 27(1), pp.12-18. Available at: <https://www.jstor.org/stable/40165162> [Accessed 1 September 2020].

Bryman, A., 2012. Social Research Methods. 4th ed. Oxford University Press: Oxford University Press, pp.468-500.

Campbell, D., 1965. Ethnocentric and other altruistic motives. In: D. Levine, ed., Nebraska Symposium on Motivation. Lincoln: University of Nebraska Press, pp.283-311. 
Carver, R., 1997. Theoretical underpinnings of service learning. Theory Into Practice, [online] 36(3), pp.143-149. Available at:

<https://ezp.lib.cam.ac.uk/login?url=https://search.ebscohost.com/login.aspx?direct=true\&db=bs $\mathrm{u} \& A N=9710224707 \&$ site $=$ ehost-live \&scope $=$ site $>$ [Accessed 19 September 2020].

Clark, K.B., 1979. Introduction. In: Allport, G.W. The Nature of Prejudice. 3rd edition. New York: Perseus Publishing, ix-xi.

Clear, T., Rose, D. and Ryder, J., 2001. Incarceration and the Community: The Problem of Removing and Returning Offenders. Crime \& Delinquency, [online] 47(3), pp.335-351. Available at: <https://doi.org/10.1177/0011128701047003003> [Accessed 5 September 2020].

Coleman, J., 1990. Foundations Of Social Theory. [ebook] Cambridge, MA: Belknap Press of Harvard University Press. Available at: <https://hdl-handlenet.ezp.lib.cam.ac.uk/2027/heb.31522> [Accessed 29 August 2020].

Coleman, J., 1958. Relational Analysis: The Study of Social Organizations with Survey Methods. Human Organization, [online] 17(4), pp.28-36. Available at: <https://www-jstororg.ezp.lib.cam.ac.uk/stable/44124097> [Accessed 2 August 2020].

Cook, S., 1985. Experimenting on social issues: The case of school desegregation. American Psychologist, [online] 40(4), pp.452-460. Available at: <http://dx.doi.org.ezp.lib.cam.ac.uk/10.1037/0003-066X.40.4.452> [Accessed 17 September 2020].

Cure Violence Global, 2019. The Five Required Components Of Cure Violence. [online] Chicago: Cure Violence Global. Available at: <https://1vp6u534z5kr2qmr0w11t7ubwpengine.netdna-ssl.com/wp-content/uploads/2019/12/2019.12.12-Cure-Violence-Criteria.pdf〉 [Accessed 7 September 2020].

Dessel, A., 2010. Effects of Intergroup Dialogue: Public School Teachers and Sexual Orientation Prejudice. Small Group Research, [online] 41(5), pp.556-592. Available at:

<https://doi.org/10.1177/1046496410369560> [Accessed 16 September 2020].

DeVeaux, M., 2013. The Trauma of the Incarceration Experience. Harvard Civil Rights-Civil Liberties Law Review, [online] 48(1). Available at:

$<$ https://heinonline.org/HOL/P?h=hein.journals/hcrcl48\&i=261> [Accessed 30 August 2020].

Dewey, J., 1938. Experience \& Education. New York: Kappa Delta Pi. 
Dickert, N. and Grady, C., 1999. What's the Price of a Research Subject? Approaches to Payment for Research Participation. New England Journal of Medicine, [online] 341(3), pp.198203. Available at: <https://pubmed.ncbi.nlm.nih.gov/10403861/> [Accessed 15 September 2020].

Dillenbourg, P., 1999. What do you mean by collaborative learning?. In: P. Dillenbourg, ed., Collaborative Learning: Cognitive and Computational Approaches. [online] Oxford: Elsevier, pp.1-19. Available at: <https://telearn.archives-ouvertes.fr/hal-00190240/document> [Accessed 1 September 2020].

Dixon, J., Durrheim, K. and Tredoux, C., 2005. Beyond the Optimal Contact Strategy: A Reality Check for the Contact Hypothesis. American Psychologist, [online] 60(7), pp.697-711. Available at: <https://pubmed.ncbi.nlm.nih.gov/16221003/> [Accessed 17 September 2020].

Dweck, C., 2006. Mindset: The New Psychology Of Success. New York: Ballantine Books.

Ellis, E., 2007. An Open Letter To Our Friends On The Question Of Language. [online] Brooklyn, NY: The Center for Nuleadership on Urban Solutions. Available at: <https://cmjcenter.org/wp-content/uploads/2017/07/CNUS-AppropriateLanguage.pdf> [Accessed 7 June 2020].

Ellis, M., 2012. The Origins of the Elected Prosecutor. The Yale Law Journal, [online] 121(6), pp.1528-1569. Available at: <https://www.yalelawjournal.org/note/the-origins-of-the-electedprosecutor $>$ [Accessed 17 September 2020].

Encyclopedia Britannica. 2002. Prosecutor. [online] Available at: <https://www.britannica.com/topic/prosecutor> [Accessed 18 September 2020].

Erikson, E., 1950. Childhood And Society. New York: Norton.

Esses, V., Jackson, L. and Armstrong, T., 1998. Intergroup Competition and Attitudes Toward Immigrants and Immigration: An Instrumental Model of Group Conflict. Journal of Social Issues, [online] 54(4), pp.699-724. Available at: <https://doi.org/10.1111/j.15404560.1998.tb01244.x> [Accessed 16 September 2020].

Freitas, A. and Downey, G., 1998. Resilience: A Dynamic Perspective. International Journal of Behavioral Development, [online] 22(2), pp.263-285. Available at: <https://doi.org/10.1080/016502598384379> [Accessed 1 August 2020]. 
Fukuyama, F., 2000. Social Capital and Civil Society. IMF Working Papers, [online] 00(74), p.1. Available at:

<https://www.researchgate.net/publication/5123592_Social_Capital_and_Civil_Society> [Accessed 6 September 2020].

Fukuyama, F., 1995. Trust: Social Virtues And The Creation Of Prosperity. London: Hamish Hamilton.

Gaertner, S., Dovidio, J., Rust, M., Nier, J., Banker, B., Ward, C., Mottola, G. and Houlette, M., 1999. Reducing intergroup bias: Elements of intergroup cooperation. Journal of Personality and Social Psychology, [online] 76(3), pp.388-402. Available at: <https://doi.org/10.1037/00223514.76.3.388> [Accessed 20 September 2020].

Geller, A., Fagan, J., Tyler, T. and Link, B., 2014. Aggressive Policing and the Mental Health of Young Urban Men. American Journal of Public Health, [online] 104(12), pp.2321-2327. Available at: <https://www.ncbi.nlm.nih.gov/pmc/articles/PMC4232139/> [Accessed 29 August 2020].

Gifford, D., 1983. Meaningful Reform of Plea Bargaining: The Control of Prosecutorial Discretion. University of Illinois Law Review, [online] 1983(1), pp.37-98. Available at: <https://heinonline.org/HOL/P?h=hein.journals/unilllr1983\&i=45> [Accessed 17 September 2020].

Grady, C., 2005. Payment of clinical research subjects. Journal of Clinical Investigation, [online] 115(7), pp.1681-1687. Available at:

<https://www.ncbi.nlm.nih.gov/pmc/articles/PMC1159153/> [Accessed 15 September 2020].

Grant, R. and Sugarman, J., 2004. Ethics in Human Subjects Research: Do Incentives Matter?. The Journal of Medicine and Philosophy, [online] 29(6), pp.717-738. Available at: <https://doi.org/10.1080/03605310490883046> [Accessed 15 September 2020].

Grupe, D. and Nitschke, J., 2013. Uncertainty and anticipation in anxiety: an integrated neurobiological and psychological perspective. Nature Reviews Neuroscience, [online] 14(7), pp.488-501. Available at: <https://doi.org/10.1038/nrn3524> [Accessed 1 September 2020].

Gubbins, C. and MacCurtain, S., 2008. Understanding the Dynamics of Collective Learning: The Role of Trust and Social Capital. Advances in Developing Human Resources, [online] 10(4), pp.578-599. Available at: <https://doi.org/10.1177/1523422308320372> [Accessed 2 September 2020]. 
Haney, C., 2002. The Psychological Impact Of Incarceration: Implications For Post-Prison Adjustment. From Prison to Home. [online] Washington D.C.: U.S. Department of Health and Human Services. Available at: <http://webarchive.urban.org/publications/410624.html> [Accessed 29 August 2020].

Harlow, C., 1999. Prior Abuse Reported By Inmates And Probationers. Bureau of Justice Statistics Selected Findings. [online] Washington D.C.: U.S. Department of Justice, Bureau of Statistics. Available at: <https://www.bjs.gov/content/pub/pdf/parip.pdf> [Accessed 10 September 2020].

Helfgott, J., 1997. Ex-offender needs versus community opportunity in Seattle, Washington. Federal Probation, [online] 61(2), pp.12-24. Available at: <https://heinonline.org/HOL/P?h=hein.journals/fedpro61\&i=126> [Accessed 3 September 2020].

Hurwitz, J. and Peffley, M., 2005. Explaining the Great Racial Divide: Perceptions of Fairness in the U.S. Criminal Justice System. The Journal of Politics, [online] 67(3), pp.762-783. Available at: <https://doi.org/10.1111/j.1468-2508.2005.00338.x> [Accessed 19 August 2020].

Inside-Out Prison Exchange Program. 2020. The Network. [online] Available at: <https://www.insideoutcenter.org/network.html> [Accessed 18 September 2020].

Institute for Innovation in Prosecution at John Jay College (IIP). 2020. Inside Criminal Justice: A Replication Manual for Prosecutors and Colleges. [online]. Available at: <https://static1.squarespace.com/static/5c4fbee5697a9849dae88a23/t/5f05d2c6bc1a624a306ccff 6/1594217204425/ICJ+Replication+Manual.pdf> [Accessed 11 August 2020].

Institute for Innovation in Prosecution at John Jay College (IIP). 2019. Inside Criminal Justice. [online] Available at: <https://www.prosecution.org/inside-criminal-justice> [Accessed 16 June 2020].

Jennings, W., Piquero, A. and Reingle, J., 2012. On the overlap between victimization and offending: A review of the literature. Aggression and Violent Behavior, [online] 17(1), pp.16-26. Available at: <https://doi.org/10.1016/j.avb.2011.09.003> [Accessed 10 September 2020].

Kolm, S., 2000. The Logic of Good Social Relations. Annals of Public and Cooperative Economics, [online] 71(2), pp.171-189. Available at: <https://doiorg.ezp.lib.cam.ac.uk/10.1111/1467-8292.00139> [Accessed 28 August 2020]. 
Koschate, M. and van Dick, R., 2011. A multilevel test of Allport's contact conditions. Group Processes \& Intergroup Relations, [online] 14(6), pp.769-787. Available at: <http://10.1177/1368430211399602> [Accessed 16 September 2020].

Kuiper, K., 2011. Adversary Procedure. [online] Encyclopedia Britannica. Available at: $<$ https://www.britannica.com/topic/adversary-procedure> [Accessed 18 September 2020].

Kyndt, E., Raes, E., Lismont, B., Timmers, F., Cascallar, E. and Dochy, F., 2013. A metaanalysis of the effects of face-to-face cooperative learning. Do recent studies falsify or verify earlier findings?. Educational Research Review, [online] 10, pp.133-149. Available at: <https://doi.org/10.1016/j.edurev.2013.02.002> [Accessed 2 September 2020].

Lang, L., 2019. How to make sure they don't go back: New York State is failing at reentry. New York Daily News, [online] Available at: <https://www.nydailynews.com/opinion/ny-oped-howto-make-sure-they-dont-go-back-20191027-jkrgorrcqraxfd4pdyhb7o5lvy-story.html> [Accessed 16 June 2020].

LeBel, T., 2007. An Examination of the Impact of Formerly Incarcerated Persons Helping others. Journal of Offender Rehabilitation, [online] 46(1-2), pp.1-24. Available at: <https://doi.org/10.1080/10509670802071485> [Accessed 30 August 2020].

Liebling, A., 1999. Doing research in prison: Breaking the silence?. Theoretical Criminology, [online] 3(2), pp.147-173. Available at: 〈https://doi.org/10.1177/1362480699003002002> [Accessed 20 August 2020].

Liebling, A., 2001. Whose Side are We on? Theory, Practice and Allegiances in Prisons Research. British Journal of Criminology, [online] 41(3), pp.472-484. Available at: <https://doi.org/10.1093/bjc/41.3.472> [Accessed 25 August 2020].

Liebling, A., Laws, B., Lieber, E., Auty, K., Schmidt, B., Crewe, B., Gardom, J., Kant, D. and Morey, M., 2019. Are Hope and Possibility Achievable in Prison?. The Howard Journal of Crime and Justice, [online] 58(1), pp.104-126. Available at:

<https://doi.org/10.1111/hojo.12303> [Accessed 13 August 2020].

Llewellyn, J. and Howse, R., 1998. Restorative Justice : A Conceptual Framework. [online] Ottawa: Law Commission of Canada. Available at: <https://digitalcommons.schulichlaw.dal.ca/scholarly_works/418/> [Accessed 2 September 2020]. 
Macklin, R., 1981. 'Due' and 'Undue' Inducements: On Pasing Money to Research Subjects. IRB: Ethics and Human Research, [online] 3(5), p.1. Available at:

<https://www.jstor.org/stable/3564136> [Accessed 15 September 2020].

Mania, E., Gaertner, S., Riek, B., Dovidio, J., Lamoreaux, M. and Direso, S., 2009. Intergroup Contact: Implications for Peace Education. In: G. Salomon and E. Cairns, ed., Handbook on Peace Education. [online] New York: Taylor \& Francis, pp.87-102. Available at: <https://wwwroutledgehandbooks-com.ezp.lib.cam.ac.uk/doi/10.4324/9780203837993.ch7> [Accessed 16 September 2020].

Markus, G., Howard, J. and King, D., 1993. Integrating Community Service and Classroom Instruction Enhances Learning: Results from an Experiment. Educational Evaluation and Policy Analysis, [online] 15(4), pp.410-419. Available at: <https://www.jstor.org/stable/1164538> [Accessed 17 September 2020].

Maruna, S., 2001. Making Good: How Ex-Convicts Reform And Rebuild Their Lives. Washington D.C.: American Psychological Association.

Maruna, S., LeBel, T. and Lanier, C., 2004. Generativity behind bars: Some "redemptive truth" about prison society. The generative society: Caring for future generations., [online] pp.131-151. Available at: <https://doi.org/10.1037/10622-009> [Accessed 6 September 2020].

Maruschak, L. and Minton, T., 2020. Correctional Populations In The United States, 2017-2018. Correctional Populations in the United States Series. [online] Washington D.D.: U.S. Department of Justice, Bureau of Justice Statistics, p.2. Available at:

<https://www.bjs.gov/content/pub/pdf/cpus1718.pdf> [Accessed 24 August 2020].

Maslow, A., 1954. Motivation And Personality. New York: Harper \& Row.

McMillan, D. and Chavis, D., 1986. Sense of community: A definition and theory. Journal of Community Psychology, [online] 14(1), pp.6-23. Available at: <https://doi.org/10.1002/15206629(198601)14:1<6::AID-JCOP2290140103>3.0.CO;2-I> [Accessed 1 August 2020].

Mears, D. and Cochran, J., 2015. Prisoner Reentry In The Era Of Mass Incarceration. Los Angeles: SAGE, pp.125-144.

Merton, R., 1957. Social Theory And Social Structure. Glencoe, Illinois: Free Press.

Merton, R., 1938. Social Structure and Anomie. American Sociological Review, [online] 3(5), p.672. Available at: <https://www.jstor.org/stable/2084686> [Accessed 25 August 2020]. 
Meshel, D. and MCGlynn, R., 2004. Intergenerational Contact, Attitudes, and Stereotypes of Adolescents and Older People. Educational Gerontology, [online] 30(6), pp.457-479. Available at: <https://doi.org/10.1080/03601270490445078> [Accessed 17 September 2020].

Molina, L. and Wittig, M., 2006. Relative Importance of Contact Conditions in Explaining Prejudice Reduction in a Classroom Context: Separate and Equal?. Journal of Social Issues, [online] 62(3), pp.489-509. Available at: 〈https://doi.org/10.1111/j.1540-4560.2006.00470.x> [Accessed 17 September 2020].

Morin, R. and Stepler, R., 2016. The Racial Confidence Gap In Police Performance. [online] Washington D.C.: Pew Research Center. Available at:

<https://www.pewsocialtrends.org/2016/09/29/the-racial-confidence-gap-in-policeperformance/> [Accessed 21 August 2020].

Noy, C., 2008. Sampling Knowledge: The Hermeneutics of Snowball Sampling in Qualitative Research. International Journal of Social Research Methodology, [online] 11(4), pp.327-344. Available at: <https://doi-org.ezp.lib.cam.ac.uk/10.1080/13645570701401305> [Accessed 4 September 2020].

Paluck, E., Green, S. and Green, D., 2018. The contact hypothesis re-evaluated. Behavioural Public Policy, [online] 3(02), pp.129-158. Available at: <https://doi.org/10.1017/bpp.2018.25> [Accessed 10 March 2020].

Pager, D., 2003. The Mark of a Criminal Record. American Journal of Sociology, [online] 108(5), pp.937-975. Available at: <https://scholar.harvard.edu/pager/publications/mark-criminalrecord $>$ [Accessed 7 September 2020].

Panitz, T., 1997. Collaborative Versus Cooperative Learning: Comparing the two definitions helps understand the nature of interactive learning. Cooperative Learning and College Teaching, [online] 8(2). Available at: <https://files.eric.ed.gov/fulltext/ED448443.pdf> [Accessed 1 September 2020].

Pettigrew, T., 1998. Intergroup Contact Theory. Annual Review of Psychology, [online] 49(1), pp.65-85. Available at: 〈http://dx.doi.org.ezp.lib.cam.ac.uk/10.1146/annurev.psych.49.1.65> [Accessed 17 September 2020].

Pettigrew, T. and Tropp, L., 2006. A meta-analytic test of intergroup contact theory. Journal of Personality and Social Psychology, [online] 90(5), pp.751-783. Available at: <https://doi.org/10.1037/0022-3514.90.5.751> [Accessed 5 March 2020]. 
Pfaff, J., 2017. Locked In: The True Causes Of Mass Incarceration. New York: Basic Books.

Plummer, K., 2019. “Whose Side Are We On?” Revisited: Narrative Power, Narrative Inequality, and a Politics of Narrative Humanity. Symbolic Interaction, [online] 43(1), pp.46-71. Available at: <https://doi.org/10.1002/symb.449> [Accessed 28 August 2020].

Prochaska, J., DiClemente, C. and Norcross, J., 1992. In search of how people change: Applications to addictive behaviors. American Psychologist, [online] 47(9), pp.1102-1114. Available at: <https://ezp.lib.cam.ac.uk/login?url=https://search.ebscohost.com/login.aspx?direct=true\&db=pd h\&AN=1993-09955-001\&site=ehost-live\&scope=site $>$ [Accessed 3 July 2020]

Purtle, J., Dicker, R., Cooper, C., Corbin, T., B. Greene, M., Marks, A., Creaser, D., Topp, D. and Moreland, D., 2013. Hospital-based violence intervention programs save lives and money. Journal of Trauma and Acute Care Surgery, [online] 75(2), pp.331-333. Available at: <https://doi.org/10.1097/TA.0b013e318294f518> [Accessed 31 August 2020].

Rabuy, B. and Kopf, D. (2015). Prisons of Poverty: Uncovering the pre-incarceration incomes of the imprisoned. [online] Prison Policy Initiative. Available at: https://www.prisonpolicy.org/reports/income.html [Accessed 5 Sept. 2020].

Rock, P., 2017. The Foundations of Sociological Theories of Crime. In: A. Liebling, S. Maruna and L. McAra, ed., The Oxford Handbook of Criminology, 6th ed. Oxford: Oxford University Press, pp.21-56.

Rosenmerkel, S., Durose, M. and Farole, D., 2010. Felony Sentences In State Courts, 2006 Statistical Tables. Felony Sentences in State Courts Series. [online] Washington DC: U.S. Department of Justice, Bureau of Justice Statistics. Available at: <https://www.bjs.gov/content/pub/pdf/fssc06st.pdf> [Accessed 21 August 2020].

Sadler-Smith, E., 2005. Learning And Development For Managers. Oxford: Wiley-Blackwell.

Laub, J. and Sampson, R., 2003. Shared Beginnings, Divergent Lives: Delinquent Boys To Age 70. Cambridge, MA: Harvard University Press.

Sampson, R. and Laub, J., 1993. Crime In The Making: Pathways And Turning Points Through Life. Cambridge, MA: Harvard University Press. 
Sampson, R. and Lauritsen, J., 1994. Violent Victimization and Offending: Individual-, Situational-, and Community-level Risk Factors. In: A. Reiss and J. Roth, ed., Understanding and Preventing Violence, Volume 3: Social Influences. [online] Washington D.C.: National Academy Press, pp.1-114. Available at: <https://www.nap.edu/read/4421/chapter/2> [Accessed 10 September 2020].

Senge, P., 1990. The Fifth Discipline Fieldbook. The Art \& Practice Of Learning Organization. New York: Doubleday.

Shapland, J. and Bottoms, A., 2011. Reflections on social values, offending and desistance among young adult recidivists. Punishment \& Society, [online] 13(3), pp.256-282. Available at: <https://doi.org/10.1177/1462474511404334> [Accessed 15 September 2020].

Sherif, M., Harvey, O., White, B., Hood, W. and Sherif, C., 1988. The Robbers Cave Experiment: Intergroup Conflict And Cooperation. [ebook] Middletown, CT: Wesleyan University Press. Available at: <https://ebookcentral.proquest.com/lib/cam/reader.action?docID=776715\&ppg=1> [Accessed 16 September 2020].

Smith, A., 2001. Can You Be a Good Person and a Good Prosecutor?. Georgetown Journal of Legal Ethics, [online] 14(2), pp.355-400. Available at:

<https://ezp.lib.cam.ac.uk/login?url=https://www-proquestcom.ezp.lib.cam.ac.uk/docview/227348342?accountid=9851> [Accessed 19 September 2020].

Stephan, W. and Finlay, K., 1999. The Role of Empathy in Improving Intergroup Relations. Journal of Social Issues, [online] 55(4), pp.729-743. Available at: <https://doi.org/10.1111/00224537.00144> [Accessed 3 September 2020].

Stephan, W. and Stephan, C., 1985. Intergroup Anxiety. Journal of Social Issues, [online] 41(3), pp.157-175. Available at: <https://doi.org/10.1111/j.1540-4560.1985.tb01134.x> [Accessed 15 September 2020].

Sykes, G. (1958). The Society of Captives: A Study of a Maximum- security Prison. Princeton: Princeton University Press, pp.63-84.

Tajfel, H. and Turner, J., 1979. An Integrative Theory of Intergroup Conflict. In: W. Austin and S. Worchel, ed., The social psychology of inter-group relations. [online] Monterey, CA: Brooks/Cole, pp.33-47. Available at: <https://www.alnap.org/help-library/an-integrative-theoryof-intergroup-conflict> [Accessed 20 May 2020]. 
Tausczik, Y. and Pennebaker, J., 2009. The Psychological Meaning of Words: LIWC and Computerized Text Analysis Methods. Journal of Language and Social Psychology, [online] 29(1), pp.24-54. Available at: <https://doi.org/10.1177/0261927X09351676> [Accessed 20 July 2020].

Taylor, D., 2020. George Floyd Protests: A Timeline. The New York Times, [online] Available at: <https://www.nytimes.com/article/george-floyd-protests-

timeline.html action=click\&pgtype=Article \&state=default \&module=styln-george-

floyd\&variant=show\&region=TOP_BANNER\&context=storylines_menu $>$ [Accessed 22 August 2020].

Todd, A. and Galinsky, A., 2014. Perspective-Taking as a Strategy for Improving Intergroup Relations: Evidence, Mechanisms, and Qualifications. Social and Personality Psychology Compass, [online] 8(7), pp.374-387. Available at: <https://doi.org/10.1111/spc3.12116> [Accessed 1 September 2020].

Travis, J., Stewart, C. and Goldberg, A., 2019. Prosecutors, Democracy, And Justice: Holding Prosecutors Accountable. Executive Session Papers. [online] New York City: Institute for Innovation in Prosecution. Available at:

<https://static1.squarespace.com/static/5c4fbee5697a9849dae88a23/t/5d6d8d224f45fb00014076 d5/1567460643414/Prosecutors\%2C+Democracy\%2C+Justice_FORMATTED+9.2.19.pdf> [Accessed 20 September 2020].

Tyler, T., 2003. Procedural Justice, Legitimacy, and the Effective Rule of Law. Crime and Justice, [online] 30, pp.283-357. Available at: 〈https://www.jstor.org/stable/1147701> [Accessed 14 September 2020].

US Sentencing Commission, 2019. 2019 Annual Report And Sourcebook Of Federal Sentencing Statistics. Sourcebook of Federal Sentencing Statistics. [online] Washington D.C.: US Sentencing Commission, pp.56-60. Available at: <https://www.ussc.gov/research/sourcebook2019> [Accessed 24 August 2020].

Vygotsky, L. and Cole, M., 1978. Mind In Society: The Development Of Higher Psychological Processes. Cambridge, Mass: Harvard University Press.

Webster, D., Whitehill, J., Vernick, J. and Parker, E., 2012. Evaluation Of Baltimore'S Safe Streets Program: Effects On Attitudes, Participants' Experiences, And Gun Violence. [online] Baltimore, MD: Johns Hopkins Bloomberg School of Public Health. Available at: <https://1vp6u534z5kr2qmr0w11t7ub-wpengine.netdna-ssl.com/wpcontent/uploads/2019/09/Safe-Streets-full-evaluation-1.pdf> [Accessed 8 September 2020]. 
Wical, W., Richardson, J. and Bullock, C., 2020. A Credible Messenger: The Role of the Violence Intervention Specialist in the Lives of Young Black Male Survivors of Violence. Violence and Gender, [online] 7(2), pp.66-69. Available at: <https://doi.org/10.1089/vio.2019.0026> [Accessed 6 September 2020].

Wolff, N. and Draine, J., 2004. Dynamics of Social Capital of Prisoners and Community Reentry: Ties That Bind?. Journal of Correctional Health Care, [online] 10(3), pp.457-490. Available at: <https://doi-org.ezp.lib.cam.ac.uk/10.1177/107834580301000310> [Accessed 3 September 2020].

Wolff, N. and Shi, J., 2012. Childhood and Adult Trauma Experiences of Incarcerated Persons and Their Relationship to Adult Behavioral Health Problems and Treatment. International Journal of Environmental Research and Public Health, [online] 9(5), pp.1908-1926. Available at: <https://doi.org/10.3390/ijerph9051908> [Accessed 10 September 2020].

Wolff, N., Shi, J. and Siegel, J., 2009. Patterns of Victimization Among Male and Female Inmates: Evidence of an Enduring Legacy. Violence and Victims, [online] 24(4), pp.469-484. Available at: <http://dx.doi.org.ezp.lib.cam.ac.uk/10.1891/0886-6708.24.4.469> [Accessed 11 September 2020].

World Prison Brief, Institute for Crime \& Justice Policy Research. (2019). Highest to Lowest Prison Population Rate | World Prison Brief. [online] Available at:

https://www.prisonstudies.org/highest-tolowest/prison_population_rate?field_region_taxonomy_tid=All [Accessed 15 Aug. 2020].

Wright, M., 2000. Getting More out of Less: The Benefits of Short-Term Experiential Learning in Undergraduate Sociology Courses. Teaching Sociology, [online] 28(2), pp.116-121. Available at: <https://www.jstor.org/stable/1319259> [Accessed 20 September 2020].

Wright, R., 2009. How Prosecutor Elections Fail Us. Ohio State Journal of Criminal Law, [online] 6(2), pp.581-610. Available at:

<https://kb.osu.edu/bitstream/handle/1811/73077/OSJCL_V6N2_581.pdf> [Accessed 20 September 2020].

Zehr, H., 1990. Changing Lenses: A New Focus For Crime And Justice. [ebook] Scottsdale, Pennsylvania: Herald Press. Available at: <https://ezp.lib.cam.ac.uk/login?url=https://search.ebscohost.com/login.aspx?direct=true \&db=nl ebk\&AN=28157\&site=ehost-live \&scope $=$ site\&ebv=EB\&ppid=pp_3> [Accessed 5 September 2020]. 


\section{Appendix A: Interview schedule}

\section{Background Assessment}

I have here that you graduated with the (year) cohort at (facility). Is that correct?

1. Tell me a little bit about yourself. What would you like me to know about who you are? Probes: What is important to you? What do you like to do?

\section{Tell me about your life since you graduated from the course.}

Probes: Have you achieved any particular goals/milestones? (For formerly incarcerated students) How has your transition back home been?

3. How long have you been involved with the criminal justice system?

Probes: (For prosecutors) How long have you been in law enforcement?

\section{Anchoring questions}

4. Why did you decide to participate in the course?

Probes: What was it that first drew you to ICJ (i.e. flyer, word-of-mouth, recommendation of a colleague or fellow student, opportunity for credit)? What were you hoping for?

\section{Tell me about your first class.}

Probes: What stands out to you about that first day? Can you tell me about the exercises that you did, if you can remember?

6. What made you want to stay in the course?

Probes: What was the classroom atmosphere like? What kinds of interactions did you have with your fellow students?

7. Looking back, is there anything about the course (i.e. reading, interactive exercises, class discussion) that were particularly useful or powerful that stayed with you? 
Probes: What memories from the course do you have that jump out at you? What readings or discussions do you remember? Was there a memorable class exercise that you did? Was there something that let you see from another person's perspective?

\section{What do you remember about the graduation ceremony?}

Probes: Do you remember how you felt that day? What was your group's policy proposal? Were there any proposals or ideas shared that day that stand out to you?

For incarcerated students:

\section{Is there anything about the course that did or didn't help with your transition} home?

-Probes: What did you learn that made it easier or harder to come back? Did you connect with anyone that helped you in your transition? $\rightarrow$ If yes, who did you connect with and how did they help?

For prosecutors:

9. In a moment of change and transition nationally, did the course equip you to think about the evolving landscape of justice?

-Probes: Have you changed any of your positions professionally? Did the class help you to create a framework to understand the broader efforts for change?

\section{Class Impact on Preexisting Beliefs about the Criminal Justice System}

\section{Prior to this course, what were your opinions of (prosecutors/law enforcement)? Of incarcerated people?}

Probes: How would you describe someone in law enforcement? How would you describe someone who is incarcerated? What characteristics would you say someone in law enforcement has? What characteristics would you say someone who is incarcerated has? What does your family/community think about law enforcement? What does your family/community believe about incarcerated people?

\section{Through this course did any of your ideas about the criminal justice system change?}


-Probes: Were any of them challenged? If so, how? How did you deal with those challenges to your ideas? What did you learn that was particularly surprising?

\section{What did you learn from the personal change project exercise?}

Probes: What did you learn about yourself? What did you learn about other people/your classmates? When you have made new changes after the course, do you use anything you learned?

13. Was there a moment during the course of ICJ that was particularly impactful to your thinking? Can you tell me about it?

-Probes: Was there a conversation that you had with your peers or your instructors that changed your mind about something? Was there something that you learned that really surprised you? Can you describe that moment? Can you describe what that experience felt like (i.e. emotions)?

\section{Was there something in particular that changed your mind?}

Probes: Was there something someone said during the course? Did you have a conversation during or after the course that changed your thinking?

\section{Would this course have been more useful to you if you took it at a different time in your} career/life?

Probes: Do you think this knowledge could have helped you make different choices? Would this experience have been more beneficial in your life later? Can you think of any particular situations or cases that you might have handled differently with the knowledge you have now?

16. What impact has the course had on your ideas about how to support people before they enter the system?

Probes: What kind of programs or systems could be put in place to prevent people from becoming system-involved? 
17. What impact has the course had on your ideas about how to support people when they enter the system?

Probes: What kind of programs or resources should be available to people entering prison and jail? What do you think people need as they are beginning and throughout their incarceration?

18. What impact has the course had on your ideas about how to help people be successful when they exit the system?

Probe: What do people need to succeed as they reenter society? What kind of programs or resources could help them navigate their return home successfully?

For prosecutors:

18a. What did you learn about prison and about the reentry process?

Probes: Was there anything that surprised you?

19. If you could change one thing about the criminal justice system, what would it be and why?

Probes: Think about the process of developing your policy proposal.

\section{Concrete Changes in Actions/Behaviors}

20. Did the course have any kind of lasting impact on you? If so, in what ways?

-Probes: Have you attended any protests or participated in any activism activities (i.e. writing to local/state officials, signing petitions, trainings, etc)? Have you continued to learn about issues in criminal justice (i.e. going to related talks, conferences, workshops)? Have you engaged in critical conversations about these issues with others in your life?

For prosecutors

21. Do you think about your job differently? Did the course have any impact on the way you do your job?

For students: 
21. Do you do anything differently now that you are home based on your experiences in the course?

22. Has the course given you tools to argue for change in the justice system or other systems?

Probes: Did the course give you new ways of talking about different issues? Have you argued for topics that you covered in the course? Have you argued for a more rehabilitative framework?

23. How do you feel about your ability to identify things that are not working around you and to make a positive change?

Probes: How empowered do you feel to change things that you don't like around you? How does that compare to when you started the course?

Changes in Social Networks (i.e. employment, community support, and education)

24. What relationships or connections have you developed as a result of participating in ICJ?

- Follow up: (Can be individuals, employment, education, etc.) Who did you connect with in the course (can be peers, guest speakers, staff, instructors)? What organizations (if any) did you connect with that were helpful to you?

\section{Were any of the relationships that you formed unexpected? How so?}

-Probes: Did you form relationships with people that you didn't think you would at the beginning of the course? Why didn't you think you could have a relationship (i.e. friendship, peership, etc)? What barriers initially stood in your way from forming those relationships?

26. Has ICJ had any impact on any of your pre-existing relationships? If so, how and why do you think so?

-Probes: Has the course impacted the way you interact with your friends? Coworkers? Family members? If so, can you describe it? Do you discuss topics differently? Has it opened any lines of communication that weren't there previously? 
27. How has your network of people that you can contact changed, if at all?

-Probe: Do you feel like you got to know anyone who could help you take your next steps, whatever those may be? Who are those people? How have you maintained those relationships since you have finished the course?

28. What do you value about the relationships and connections you made as a result of being in the course?

\section{Do you think that your participation in this course will have an impact on your} community? In what way?

-Probes: Do you feel like you want to be more or less engaged with your community? What have you taken away from the course and applied to your community?

\section{Concluding questions:}

30. Do you have any recommendations for doing the course differently?

Probes: Are any particular issues that would be good for proposals? Is there any topic that you would spend more time on? What topics or readings would you remove?

31. What is the best thing that has happened to you since you completed the course?

Probes: What are you most proud of? Can you tell me about an achievement that happened to you? What celebrations or events stand out in your mind?

32. Finally, I'd like to ask you a question that we have been asking all of our participants across many programs. What does justice look like?

\section{Do you have any questions for me?}

Probes: Was anything unclear? Is there any question or topic that you would like to say more about or return to? 


\title{
Appendix B: Study participant information and consent form
}

\author{
INFORMED CONSENT FORM \\ TITLE OF STUDY \\ Inside Criminal Justice Seminar, Evaluation \\ Principal Investigator \\ Geraldine Downey \\ Co-Investigator \\ Claudia P. Rincón \\ Email: cr85@columbia.edu
}

Protocol Number: AAAS8722

\section{PURPOSE OF STUDY}

You are being asked to take part in an evaluation study. The purpose of this evaluation is to examine the impact of the Inside Criminal Justice Seminar on those who were part of the seminar. Before you decide to participate in this evaluation, it is important that you understand why the research is being done and what it will involve. Please read the following information carefully.

\section{STUDY PROCEDURE}

This evaluation will consist of a structured 30-45 minutes interview session to capture your experiences with the course and reflections. This will allow for further explanation and better understanding of the themes and trends across experiences. Interviews will be conducted by Zoom. Interviewers will both take notes on a computer as well as record the audio. All data about the study will be kept on secure computers only accessible by the study team. The data will be compiled and processed. Any written information will not contain any identifying information or characteristics that could trace back to the identity of participants.

RISKS

The risks in this study are considered minimal. While the research team will do everything possible to maintain confidentiality, one potential risk of participation in the study is loss of confidentiality. There are no anticipated or expected risks, significant stresses, or adverse reactions. However, anyone who experiences an adverse or negative reaction during the evaluation is free to withdraw at any time. Participation in this study is voluntary. Refusal to participate will involve no penalty or loss of benefits to which you are otherwise entitled. You may stop participating in the study at any time without penalty or loss of benefits to which you are otherwise entitled.

\section{BENEFITS}

There are no direct benefits to you for participation other than the opportunity to provide feedback that may lead to program improvements. 


\section{ALTERNATIVE PROCEDURES}

The alternative procedures for this study are not participating in the study or withdrawing from the study at any point. In neither case will the participant be penalized in any way.

\section{CONFIDENTIALITY}

Personal identifying information (e.g. name, telephone number or email) will be stored separately from the interview data and any identifying information will be permanently removed from your data. We would like to store the interview data that you provide as part of this study and use them for future use. The data will be stored in a secure, electronic, password-protected computer accessible only by the study team and Columbia University's Institutional Review Board (IRB). If your data is given to researchers who are not researchers on this study, they will be given in de-identified form. This means that your name and other identifying information will be removed. Only the research team and the Columbia Institutional Review Board (IRB), and the federal Office of Human Research Protections will have access to any information.

\section{COMPENSATION}

Participants will be compensated $\$ 40$ for completing this interview. Payment will be given to the participants in the form of a gift card mailed to an address provided by the participant after completion of the study.

\section{CONTACT INFORMATION}

If you have questions at any time about this study, or you experience adverse effects as a result of your participation, you may contact the researcher whose contact information is provided above. If you have questions regarding your rights as a research participant, or if problems arise which you do not feel you can discuss with the Primary Investigator, please contact the Columbia IRB via email at askirb@columbia.edu or via phone at (212) 305-5883.

\section{CONSENT}

This form verifies that you have voluntarily consented to participate in a $30-45$ minute interview about your involvement in the Inside Criminal Justice Program. Participation in this interview is entirely your choice. We will do everything we can to protect your privacy. The information disclosed during this interview will only be accessible to the Center for Justice team and all identifiable attributes will be removed if we use any of this content for future research or reporting purposes. With your permission, we will audio record today's interview so that our notes can accurately capture information shared.

\section{STATEMENT OF CONSENT}

I have read this consent form and the research study has been explained to me. I agree to be in the research study described above. A copy of this consent form will be provided to me. By agreeing to participate, I have not given up any of the legal rights that I would have if I were not a participant in the study. 


\section{Appendix C: ICJ interview participant demographics}

\begin{tabular}{|l|l|}
\hline Participant type & Number of participants in sample \\
\hline ADA students & 14 \\
\hline Formerly incarcerated students & 7 \\
\hline Total & 21 \\
\hline
\end{tabular}

\begin{tabular}{|l|l|}
\hline Facility $^{\mathbf{5}}$ & Number of participants in the sample \\
\hline ECF & 3 \\
\hline LCF & 2 \\
\hline QCF & 16 \\
\hline EMTC & 1 \\
\hline Total & 22 \\
\hline
\end{tabular}

\begin{tabular}{|l|l|}
\hline Semester & Number of participants in sample \\
\hline Spring 2018 & 6 \\
\hline Fall 2018 & 2 \\
\hline Spring 2019 & 5 \\
\hline Summer 2019 & 1 \\
\hline Fall 2019 & 9 \\
\hline Total & 23 \\
\hline
\end{tabular}

${ }^{5}$ Participants who also taught the course are counted for each semester they participated in ICJ, thus the Facility and Semester totals are over 21; one participant stayed at the same facility, while the other participated and taught in separate facilities. 


\section{Appendix D: Resource sheet for study participants (abbreviated)}

Thank you for sharing your thoughts about your experience with the Inside Criminal Justice seminar course. Below, please find a list of organizations serving formerly incarcerated people in the New York City area.

\section{College Initiative at John Jay's Institute for Justice and Opportunity (formerly the Prisoner Reentry Institute)}

Description: More than one thousand previously incarcerated or court-involved students have pursued higher education through College Initiative, a college preparation program and community. Nearly 400 have earned post-secondary degrees, and roughly $20 \%$ of those graduates have earned multiple degrees. Founded as an independent nonprofit organization in 2002, CI merged with the Institute for Justice and Opportunity in 2015. College Initiative's three pillars-academic counseling, peer mentoring, and community support-help students grow as learners and as leaders.

What is offered: academic counseling, peer mentoring, workshops, and professional development

Contact: Information form on website page (please complete first!); Codi Haigney, Support Services Program Associate, 646-781-5231, chaigney@jjay.cuny.edu

Website: https://justiceandopportunity.org/educational-pathways/college-initiative/

\section{The Coming Home Program at Mount Sinai:}

Description: Since 2006, the Coming Home Program has worked to improve the physical and mental health and emotional and social well-being of men and women during their transition from prison or jail to the community. Supportive counseling, individually and in groups, and case management is offered from formerly incarcerated staff who truly understand the challenges of coming home. In addition, the Coming Home Program team trains all medical providers, clinicians and staff in the IAM to ensure that formerly incarcerated patients receive their health 
care in a safe and welcoming environment. Program services include physicals, specialist referrals, mental health and wellness programming, case management, anger management, and more. Coming Home Program services are open to all formerly incarcerated individuals, regardless of how long they have been home.

What is offered: healthcare, mental health, wellness, case management

Contact: Iris Bowen, LMSW, Coming Home Program Coordinator (212-636-1173), to make an appointment call (212-523-6500) or email ComingHome@mountsinai.org

\section{The Fortune Society}

Description: Founded in 1967, The Fortune Society's vision is to foster a world where all who are incarcerated or formerly incarcerated will thrive as positive, contributing members of society. The Fortune Society's mission is to support successful reentry from incarceration and promote alternatives to incarceration, thus strengthening the fabric of our communities. We do this through a holistic, one-stop model of service provision. Our continuum of care, informed and implemented by professionals with cultural backgrounds and life experiences similar to those of our participants, helps ensure their success. Fortune serves over 8,000 individuals annually via three New York City locations: our service center in Long Island City, Queens, and both the Fortune Academy ("the Castle") and Castle Gardens in West Harlem.

What is offered: housing, education, employment services, mental health treatment, health services, benefits application assistance, alternatives to incarceration programs

Contact: Long Island City main office: 212-691-7554; email: info@fortunesociety.org

Website: https://fortunesociety.org/

\section{The Osborne Association}

Description: The Osborne Association works in partnership with individuals, families, and communities to create opportunities for people affected by the criminal justice system to further 
develop their strengths and lead lives of responsibility and contribution. More than 300 staff in community sites in New York City, Newburgh, NY, Buffalo, and more than 30 prisons and jails work at every point of the continuum, from arrest and pre-entry, through jail and prison, to reentry, including children and families affected by crime and the criminal justice system. We are known for developing effective programs that offer a broad range of treatment, education, and vocational services to more than 12,000 people each year.

NYC Reentry Hotline: Callers can receive referral information for any reentry needs, such as medical services, mental health services, housing, entitlements, and COVID specific concerns.

What is offered: NYC Reentry Hotline, employment services, substance use treatment

Contact: Brooklyn Center: 718-637-6560, Bronx Center: 718-707-2600, Manhattan Center:

212-324-5577; NYC Reentry Hotline 1-833-OSB-FREE (1-833-672-3733) [Open everyday from 8am to 8pm]; Steuben Vega (svega@ osborneny.org) for employment services

Website: http://www.osborneny.org/ 


\section{Appendix E: Considerations for practitioners of ICJ}

The following document includes a brief list of considerations for individuals or organizations looking to implement the ICJ model in their respective jurisdictions, based on interviews with past participants. These are meant for review in tandem with the ICJ Replication Manual (IIP, 2020).

\section{Considerations in participant selection}

Open to new perspectives and having the "right reasons": It is critical to ensure that all participants in ICJ are open-minded to the experiences of others or have adopted a change mindset. They do not need to be "liberal" per se, but should be open to thoughtfully considering new perspectives. An individual who is close-minded and unempathetic could potentially cause harm both to the group dynamic and to other classmates who may share deeply personal or vulnerable experiences:

We started off with sharing personal experiences to build connection...And so, it could be harmful if everyone who's already walking in kind of guarded and reserved is made even more so because there's somebody who just wholeheartedly disagrees with reform and doesn't see incarcerated people as the nuanced people that they are. (Prosecutor 07)

In a similar vein to Prosecutor 07, a student also suggested a need to evaluate the motivations of prospective participants before they enter the classroom so that the learning space becomes a place where everyone feels comfortable:

Yo, I ain't gonna lie, I'm gonna say you gotta have a referral, man....So we know that this is the right fit for you....I was just wondering like, 'why are you here?'...Are you trying to make the change or you just care to want to know the criminal mind or some shit....certain people might have had different agendas on why they was there....So I just want to make sure everybody's on the same page that way nobody don't feel like somewhere they don't need to be, or they feeling uncomfortable because if everybody's 
on the same page and everybody's on the same agenda, I'm pretty sure that nobody's going to in the room, it's going to feel uncomfortable. (Student 07)

Consistency: Cohorts that had the most meaningful impact for participants were those in which there was consistency in the class. There will be unavoidable events that will cause some participants to miss class, however, as much as possible, it is best for those who begin on the first day to continue through to the end. This allows a continuous process of trust-building to occur among participants, leading to more frank and ultimately fruitful conversations. Each time a new person is added, time must be spent rebuilding the group identity and bond:

We did make, I think it was two exceptions to take students in the second week. That was fine, but...it's very important to have that development as a group. That gets tricky as people are added...it's just because they haven't been there from day one to go through that whole transformation. (Prosecutor 05)

While to some extent, issues with correctional consistency will be beyond the control of the program, this need for consistency is equally important for ADA participants to abide by as well. One student cited frequent absences and inconsistency as a barrier to establishing trust:

It made it harder to trust [the prosecutors] in general because of the differences in the people that came in and out. Cause the ones that did stay there, they eventually had conclusion "A", but grew A to B to $\mathrm{C}$ with the class, but only the ones that had conclusion "A" you're just like, fuck that guy, he would lock any of us up in a second. (Student 03)

When a participant is not consistently involved, they miss out on the natural group evolution and cohesion that occurs with increased exposure and trust. Without trust firmly established between classmates as bedrock to the course, discussions about more contentious topics like race, and inequalities in the justice system become at best, less meaningful and honest, and at worst, nearly impossible.

\section{Ensuring course material is relevant, responsive and concrete}


When planning the syllabi and supplemental readings, some consideration should be given to the context of the correctional facility. That is to say, while the readings can be impactful regardless, when tailored to the population, both along the lines of gender and history of justice involvement. For example, material centered on men serving long sentences for serious violent crime did not resonate as deeply when used at a work-release facility with female students completing shorter sentences. The readings that were most impactful to participants were those that were more case-study focused, rather than theoretically dense. The one notable exception to this was Bronfenbrenner's Bioecological Model of Development: while the article itself was challenging, the model was one that resonated with many participants when it was distilled in class discussions and offered a useful framework to ground the course in.

\section{Creating a way to stay in touch before the course is over}

Several interviewees had plans to keep in touch with their fellow classmates that were derailed by COVID. Having a network for course alumni to connect with should be a priority in setting up the course. In its absence, the onus to remain connected frequently fell to individuals, which for some, caused disappointment and the sense that the course had ended at graduation when plans fell through. A centralized network could create a safety net for individuals to remain linked to their classmates and to the course, even if individuals lose contact with each other. Some of the earliest cohorts of ICJ organized outings to various local museums or invitations to events around criminal justice reform. In the era of COVID, it becomes even more crucial to think of creative and accessible ways for individuals to connect in the digital sphere. Technological accessibility is an important consideration, particularly for students returning home who will have varying degrees of comfort and access.

\section{Meaningful and systematic review of policy proposal by review body}

While many felt the policy project was one of the most fruitful learning exercises in the course, participants also expressed disappointment that more was not done with the ideas proposed. Two students expressed pessimism about the ability to enact meaningful change post-graduation. Both expressed feeling optimistic upon the course's completion, but disappointment in the lack of concrete deliverables resulting from the policy proposals: "But there was a sense of feeling that we had afterwards that we could enact real change. Granted, none of that happened." (Student 
03). Participants wanted the policy proposals to extend beyond a thought exercise, and translate to something concrete. As captured by the participant below, many alumni wanted their experience to mean something beyond personal benefits:

[U]s sitting, even in a Zoom session right now, frankly, is not helping them at all, unless we actually then use this conversation as a springboard for action...I'm doing this because I really do hope that it will result in something concrete. Whether it's just the smallest thing, whatever it is, something that I can feel like I contributed to in some way." (Prosecutor 08)

One participant suggested implementing a review system to ensure that all proposals presented by ICJ graduates were meaningfully and thoughtfully considered. A system similar to a formal grant review process would prevent ideas from falling through the cracks:

I think there should be a commitment that every policy proposal that is made not only gets seriously considered in an explicit way, where it's not just going into some amorphous fucking purgatory, but where it is going to go through a series of committees who are going to vote on these things and get back and request whatever it needs to be. There needs to be a system and format for really digesting some of these ideas and a sincere commitment to incorporate every single one of them in some way. There have to be teeth on this. (Prosecutor 03) 